NBER WORKING PAPER SERIES

\title{
BOND MARKETS AS CONDUITS FOR CAPITAL FLOWS: HOW DOES ASIA COMPARE?
}

\author{
Barry Eichengreen \\ Pipat Luengnaruemitchai \\ Working Paper 12408 \\ http://www.nber.org/papers/w12408
}

\author{
NATIONAL BUREAU OF ECONOMIC RESEARCH \\ 1050 Massachusetts Avenue \\ Cambridge, MA 02138 \\ July 2006
}

University of California and International Monetary Fund, respectively. The views expressed are those of the authors and should not be attributed to the International Monetary Fund, its Executive Board or its management. This draft is a revision of a paper prepared for the East Asian Seminar on Macroeconomics, Kona, Hawaii, 22-24 June 2006. The views expressed herein are those of the author(s) and do not necessarily reflect the views of the National Bureau of Economic Research.

(C)2006 by Barry Eichengreen and Pipat Luengnaruemitchai. All rights reserved. Short sections of text, not to exceed two paragraphs, may be quoted without explicit permission provided that full credit, including (C) notice, is given to the source. 
Bond Markets as Conduits for Capital Flows: How Does Asia Compare?

Barry Eichengreen and Pipat Luengnaruemitchai

NBER Working Paper No. 12408

July 2006

JEL No. F0, F3

\begin{abstract}
$\underline{\text { ABSTRACT }}$
We use data on the extent to which residents of one country hold the bonds of issuers resident in another as a measure of financial integration or interrelatedness, asking how Asia compares with Europe and Latin America and with the base case in which the purchaser and issuer of the bonds reside in different regions. Not surprisingly, we find that Europe is head and shoulders above other regions in terms of financial integration. More interesting is that Asia already seems to have made some progress on this front compared to Latin America and other parts of the world. The contrast with Latin America is largely explained by stronger creditor and investor rights, more expeditious and less costly contract enforcement, and greater transparency that lead to larger and better developed financial systems in Asia, something that is conducive to foreign participation in local markets and to intra-regional cross holdings of Asian bonds generally. Further results based on a limited sample suggest that one factor holding back investment in foreign bonds in East Asia may be limited geographical diversification by mutual funds, in turn reflecting a dearth of appropriate assets. Asian Bond Fund 2, by creating a passively managed portfolio of local currency bonds potentially attractive to mutual fund managers and investors, may help to relax this constraint.
\end{abstract}

\author{
Barry Eichengreen \\ Department of Economics \\ University of California \\ Berkeley, CA 94720 \\ and NBER \\ eichengr@econ.berkeley.edu
}

Pipat Luengnaruemitchai

International Monetary Fund

Washington, DC 20431

1pipat@imf.org 


\section{Bond Markets as Conduits for Capital Flows: How Does Asia Compare? ${ }^{1}$ Barry Eichengreen and Pipat Luengnaruemitchai July 2006}

\section{Introduction}

Bond market development is high on the policy agenda in East Asia, with the Asian Bond Fund, the Asian Bond Markets Initiative, and a range of related policy initiatives. ${ }^{2}$ Building bond markets is designed to free Asian economies from excessive dependence on bank intermediation and to foster the development of a more diversified and efficient financial sector. One can think of the desired results as having both domestic and international dimensions. Domestically, banks have the weakness of being closely connected to business and political leaders but also the strength of long-standing relationships with borrowers, enabling them to bridge information gaps that might otherwise impede lending and borrowing. Bond markets have the opposite strengths and weaknesses: transactions are at arm's length, often between anonymous buyers and sellers, but access to the bond market

\footnotetext{
${ }^{1}$ University of California and International Monetary Fund, respectively. The views expressed are those of the authors and should not be attributed to the International Monetary Fund, its Executive Board or its management. This draft is a revision of a paper prepared for the East Asian Seminar on Macroeconomics, Kona, Hawaii, 22-24 June 2006.

${ }^{2}$ The Asian Bond Fund (ABF) launched by the Executives' Meeting of East Asia-Pacific Central Banks (EMEAP) in June 2003 is designed to catalyze the growth of Asian bond markets by allocating a portion of the reserves of regional central banks to purchases of government and quasi-government securities. The initial $\$ 1$ billion of investments, known as ABF-I, was devoted exclusively to Asian sovereign and quasi-sovereign issues of dollar-denominated bonds. ABF-II is twice as large and includes bonds denominated in regional currencies. It has two components: a $\$ 1$ billion central bank reserve pool to be overseen by professional managers for local bond allocation, and a $\$ 1$ billion index unit designed to list on eight stock exchanges beginning with Hong Kong in 2005. The latter is designed to facilitate one-stop entry for retail and institutional buyers as well as providing a benchmark structure for tracking pan-Asian performance. The Asian Bond Markets Initiative (AMBI), endorsed by ASEAN+3 finance ministers at their meeting in Manila in August 2003, is designed to foster an active and liquid secondary market in local-currency bonds and to develop the infrastructure needed for the growth of local bond markets, mainly through the activity of six working groups and a focal group intended to coordinate their activities.
} 
as a source of finance is available only to the largest, longest-established firms about whom the best information is available. Given the existence of long-standing relationships between banks and their clients, the banking system is ideally placed to provide patient finance for investments subject to limited uncertainty but long gestation periods. Bond markets, in contrast, are the channel through which creditors lend to enterprises investing in rival technologies, not all of which will pay off even with sufficient time. Such are the arguments that a financially mature economy should have diversified sources of finance, including both an efficient banking system and a well developed bond market.

The international dimension emphasizes that bond markets may have advantages over banks as channels for capital flows. Banks value liquidity, given that some of their funds are raised by offering demand deposits; it follows that bank loans are generally of shorter maturity than bond issues, and the short maturity of foreign liabilities is a notorious problem for countries borrowing abroad (Goldstein and Turner 2004). Banks being too big to fail, market discipline may be weak when such institutions are on the borrowing and/or lending side of the capital flow. These qualms about bank intermediation of capital flows provided an important part of the impetus for the Asian Bond Fund and the Asian Bond Markets Initiative.

In a previous study (Eichengreen and Luengnaruemitchai 2004), we asked how Asia was doing along the domestic dimension - how Asia compared to other regions and how individual Asian countries compared to economies with broadly similar characteristics elsewhere in the world in terms of the depth of domestic markets. Here we provide a complementary analysis of the international aspect. We assess bond markets as a conduit for capital flows (more precisely, as a conduit for cumulated capital flows, that is, stocks). 
Using bilateral data we analyze the importance of a range of factors determining nonresident holdings of a country's bonds, which permits us to compare cross-country holdings in Asia with cross-country holdings in other regions, as well as analyzing the determinants of holdings across regions. This allows us to gauge the extent of bond market integration and how it compares across regions and over time. ${ }^{3}$

The vehicle for this analysis (as some readers will have guessed given use of the word "bilateral" in the preceding sentence) is the gravity model, which provides a natural framework for analyzing trade in financial assets (as well as trade in goods). An advantage of this framework is that it is straightforward to compare the results with previous gravitymodel-based studies of the determinants of cross-border capital flows mediated by international banks. ${ }^{4}$

The basic framework explains cross-country bond holdings well. The results point to the significant regionalization of bond markets in the sense that investors are most inclined to hold the bonds of other countries in their same region. Not surprisingly this phenomenon is most extensive in Europe: compared to the base case where the investors and the issuing country are in different regions, Europeans hold significantly larger bond-market claims on

\footnotetext{
${ }^{3}$ In principle, one could analyze the integration of bond markets on a number of other dimensions, for example the convergence of interest rates and spreads. Similarly, one would measure bond market development not just in terms of market capital capitalization but also liquidity (turnover), bid-ask spreads, and a number of other measures. Unfortunately, data on these other dimensions are more limited and fragmentary and thus do not permit as extensive an analysis as we undertake here (although data on stock market capitalization, utilized below, can be thought of as providing at least an indirect indication of financial market liquidity). For further discussion, see our 2004 study, and for an analysis of liquidity and spreads that expressly compares Asia with Latin America, see Eichengreen, Borensztein and Panizza (2006).

${ }^{4}$ This literature is surveyed below, in Section 2.
} 
one another. We would be alarmed and begin to question our methodology if we did not find this, since the single market, the euro and subsequent efforts at regulatory harmonization provide powerful explanations for this pattern. More striking is that cross holdings are also greater within Asia than across regions when we control for the basic arguments of the gravity model. Bond market integration in Asia may have significantly further to go before it reaches European levels or meets the expectations of regional officials, but our results suggest that there has already been some progress. ${ }^{5}$

A number of our results also caution that bond markets are not a panacea for countries seeking to tame volatile capital flows. They indicate that bond-market transactions are heavily influenced by financial conditions in the investing country, in turn suggesting that emerging economies utilizing bond markets to access foreign finance can suffer disruptions for reasons largely beyond their control. This was a conclusion of the literature analyzing early post-Brady Plan bond flows to emerging markets (see e.g. Calvo, Liederman and Reinhart 1993); it is timely again in 2006, when questions have been raised about whether flows into local bond markets reflect better fundamentals in emerging-market economies or simply the fact that the advanced economies are awash with liquidity. ${ }^{6}$ Our results also

\footnotetext{
${ }^{5}$ A contrasting case is Latin America, where we find that bond market integration, so measured, is even less than is typical of pairs of countries located in different parts of the world. This result is fully explained, it turns out, by the weakness of institutions in Latin American countries, which continues to discourage foreign investors in the region (as well as foreign investors outside) from holding their bonds - and which is associated with financial underdevelopment generally. Thus, Eichengreen, Borensztein and Panizza (2006) compare bond market development in Asia and Latin America and show that Asian countries rank significantly higher in terms of cost and reliability of contract enforcement, compliance with international accounting standards, etc.

${ }^{6}$ Empirical evidence that both sets of factors are at work is in Buchanan (2005) and Borensztein, Eichengreen and Panizza (2006a).
} 
indicate that that bondholders are attracted to the securities of countries whose returns covary positively with their own; this result would seem to support return-chasing rather than diversification motives for holding foreign bonds. This evidence of limited diversification again raises questions about the prospective stability of the market.

Section 2 starts with a review of previous studies, after which we introduce the data in Section 3. Section 4 reports the basic results, while Section 5 examines their robustness. In Section 6 we turn to the key issue of how cross-holdings of bonds within Asia and globally are related to the development of national financial systems. This leads us in Section 7 to the role institutional investors (banks, insurance companies and mutual funds). Section 8 reiterates the main findings and draws out their policy implications.

\section{Review of Previous Studies}

There are now substantial theoretical and empirical literatures using the gravity model to analyze bilateral commodity trade. Why the size and distance between importing and exporting countries should successfully explain patterns of merchandise trade is intuitive: country size is a proxy for the both the supply and demand for tradeable goods, while distance between the trading partners has is correlated with transport costs. More recently there has developed a rapidly growing if still largely unpublished literature using the gravity model to explain trade in assets. ${ }^{7}$ In that context the meaning of the distance variable is less

\footnotetext{
${ }^{7}$ In contrast to the substantial literature on bank-intermediated flows and the growing literature on equity flows, studies of the bond market - our particular concern in this paper - utilizing this framework are relatively few and far between.
} 
straightforward. ${ }^{8}$ Physical transport costs are negligible in this case; more likely is that distance to a country is correlated with availability of information about its financial instruments and the determinants of their performance (investors are likely to know more about these things in neighboring countries to which travel is relatively cheap). This perspective suggests augmenting the traditional distance measure with more direct proxies for ease of information flows, such as bilateral telephone traffic and imports and exports of newspapers and periodicals.

There is some theoretical basis for these relationships.. Martin and Rey (2004) show that if markets for financial assets are segmented, cross-border asset trade entails transaction or information costs, and the supply of assets is endogeneous, then bilateral asset holdings are positively related to the size of the markets, negatively related to the transaction or information costs, and positively related to expected returns of the assets. ${ }^{9}$ Using a similar theoretical model, Faraqee, Li and Yan (2004) also show that the gravity equation emerges naturally. While these models are developed for equity investment, one can show that the results can be applied for risky bond investments.

A. Studies using data on bank claims. From the early 1980s the Bank for International Settlements has provided information on the international claims of BISreporting banks. Banks reporting to the BIS tend to be larger and more internationally-active than the typical commercial bank, a form of selectivity that should be taken into account in

\footnotetext{
${ }^{8} \mathrm{We}$ return to this below.

${ }^{9}$ This assumption is consistent with the views that financial assets are imperfect substitutes as they insure against different risks.
} 
interpreting the finding of studies utilizing this source. ${ }^{10}$ This measure of international bank lending is organized by the country of origin of the bank extending the claims (specifically, the country in which the head office of the reporting bank is located). ${ }^{11}$ The underlying information is drawn from supervisory and statistical returns of the countries in which the banks are headquartered. Data are broken down by the national destination of the loans.

The first studies to use these data of which we are aware are by Claudia Buch. Buch (2000a) uses BIS consolidated data for one year, 1999, and limits her source countries to France, Italy, Japan, Spain, UK, and US (while distinguishing 75 destination countries). The most important determinant of the extent of cross border lending is financial development in the destination country (as measured by the ratio of bank credit to GDP). Curiously, the presence or absence of capital controls does not appear to have a significant impact on the extent of lending. In a follow-up study, Buch (2000b) then uses BIS consolidated claims data for the longer period 1983-99. In addition to the standard gravity variables, she includes in her specification the volume of bilateral trade (which enters positively and significantly, where lagged trade is used as an instrument for current trade). ${ }^{12}$ She also considers a

\footnotetext{
${ }^{10}$ A not unrelated fact is that country coverage has expanded over time. At most recent report banks and other lending institutions in some 30 jurisdictions contribute to the construction of the BIS data.

${ }^{11}$ This is in contrast to the BIS's locational data (not published on the institution's website), which distinguishes banks by location rather than nationality. Arguably, the consolidated data are more relevant for studies of financial integration insofar as they focus on both the cross-border and withindestination-country lending activities of foreign-headquartered banks.

${ }^{12}$ Rose and Spiegel (2004) focus on the connections between trade and lending as well. Their strongest finding is that an increase in trade is associated with an increase in bilateral bank lending. They instrument trade with distance and therefore do not include distance as an explanatory variable for lending. They also use a common language dummy and a regional trade agreement dummy. An alternative approach is that of Aviat and Coeurdacier (2005), who use 2001 BIS data. They estimate two simultaneous equations for trade in goods and trade in assets (using transport costs - UPS
} 
dummy for OECD membership as a measure of the differential effects of the Basle Accord (which enters positively), the Grilli-Milesi-Ferretti capital controls measure (which has a negative but quantitatively small impact on cross border bank claims), the share of the banking system that is government owned (which affects cross border lending negatively), and a measure of exchange rate volatility (which has no discernible effect on the volume of cross-border lending).

Kawai and Liu (2001) use BIS data for the period 1985-2000. They consider 10 OECD source countries and a sample of developing country destinations. Unlike other studies, they do not pool the annual data for successive years but consider a series of 16 cross sections. Like Buch, they find that trade flows encourage cross-border banking lending. In addition, the volume of bank-related inflows declines with measures of consumption and rises with the credit rating of the recipient country (especially after 1996, suggesting a growing sensitivity to credit-quality-related considerations). Countries receiving more bilateral foreign aid also receive more bank loans from the same source. In contrast to Buch's earlier conclusion, the authors find that a more volatile exchange rate discourages bank lending (this coefficient is consistently negative though not always significant). The interest differential between the source and destination country has no consistent effect.

Jeanneau and Micu (2002) study lending flows from OECD countries to 10 emerging markets. Their principal findings include that aggregate flows are procyclical with respect to

shipping rates - as an instrument for trade in goods and hence omitting it from the trade in assets equation). In addition, they compute the correlation of the average gross return on equity in the two countries. Interestingly, they find the same thing we do when we consider bonds below: a higher correlation leads to more claims (they refer to this as the "correlation puzzle"). Another study that reaches the same result is Coeurdacier and Guibaud (2005). 
growth in the lending countries. They find a positive correlation between fixed exchange rates and bank lending (reinforcing the earlier finding of Kawai and Liu). Ferrucci (2004) studies BIS-reporting banks’ lending to 19 emerging markets, and distinguishes 6 advanced lending countries. The results support the significance of business cycles in the borrowing country (but not in the lending country, which is contrary to Jeanneau and Micu), bilateral exchange rate variability (which reduces lending), the overall level of indebtedness of the borrower (which again reduces lending), bilateral trade (which enters positively), global equity returns (which enter negatively), and the yield spread between low and high rated US corporate bonds as a measure of risk tolerance (which enters negatively).

The most recent wave of studies (Eichengreen and Park 2005, Kim, Lee and Shin 2005) focuses on comparisons between Asia and Europe. To shed more light on intra-Asian flows, Eichengreen and Park (2005) supplement the BIS data with unpublished data for Taiwan, Hong Kong, Singapore and Korea. ${ }^{13}$ Banks are distinguished by nationality rather than location. They find that cross border bank claims are smaller in Asia than in Europe. The standard gravity variables explain some but by no means all of this difference. The remainder is explained by policy variables: more intra-regional trade in Europe makes for more financial flows; past capital controls influence current claims; and less developed financial markets (as measured by bank credit as a share of GDP) make for fewer flows. Kim, Lee and Shin (2005) augment the BIS data base with data for Korea. Unlike Eichengreen and Park, they report results suggesting that there is no remaining significant difference between the volume of intra-European and intra-East Asian flows once one

\footnotetext{
${ }^{13}$ Obtained from the national authorities in each country.
} 
controls for the standard gravity models. This may however reflect their limited geographical coverage for Asia.

The most comprehensive study in this vein is Papaioannou (2005), who uses BIS locational banking data from the mid-1980s through 2002. Standard gravity variables perform as expected, but there is also a role for ICRG political risk ratings, in that recent declines in country risk in developing countries have led to a significant increase in crossborder bank claims, other things equal. Papaioannou then tries to unbundle this variable by substituting bureaucratic quality (which discourages foreign bank investment), time required to complete a legal case (which has a significant negative effect on cross border bank claims), and government ownership of the banking system (which has a significant negative effect). When political risk is reintroduced, it matters as well ("politics and institutions are both key determinants of international capital transactions"). Papaioannou also considers the Reinhart-Rogoff de facto classification of exchange rate regimes and finds that foreign banks prefer investing in countries with more stable exchange rates.

Finally, Liu (2005) uses BIS data to test for the significance of General Agreement on Trade and Services (GATS) commitments - which are highly significant in his specification. In contrast to other studies, he finds no effect of exchange rate volatility or the presence of capital controls.

B. Studies using data on equity markets. An early contribution to the literature on international equity transactions is Ghosh and Wolf (2000), who consider flows from Germany, Italy, the UK and the U.S. to nine recipient countries. They include only the basic gravity variables, finding that most of these perform reasonably well. Portes and Rey (2005), in a more comprehensive effort, consider bilateral equity purchases and sales between 14 
source and destination countries in the period 1989-1996. ${ }^{14}$ They compare the performance of two measures of information costs: distance and telephone traffic. The number of bank branches in country $i$ of banks headquartered in country $j$ consistently matters, as if banks and equity-market flows are complements rather than substitutes. They use market capitalization in the source and destination countries as a measure of market size. Interestingly (and in contrast to our results for bonds below), destination country returns do not appear to matter.

Izquierdo, Morriset and Olarreaga (2003) use the same data as Portes and Rey (2005) for a similar period (1990-1996). They again use bilateral telephone traffic as a measure of information flows but also consider bilateral trade in newspapers and periodicals; by distinguishing imports and exports of newspapers they can say something about the direction of the information flow. Their most important finding, which is somewhat counterintuitive, is that information flowing from the source to the destination country matters most for bilateral equity flows (newspaper exports from the U.S. to Argentina matter more than newspaper exports from Brazil to the U.S. in explaining U.S. purchases of Brazilian equities). They interpret this as an indication of the importance of information about the liquidity of the U.S. market. $^{15}$

\footnotetext{
${ }^{14}$ The data are from Cross-Border Capital. Their Asian countries include Japan, Hong Kong and Singapore.

${ }^{15}$ In addition they attempt to identify the relationship between trade flows and financial flows, using import and export taxes as instruments in the commodity trade equation and stock market capitalization as an instrument in the equities trade equation; the two relationships are estimated simultaneously.
} 
C. Studies using data on bonds. Studies concerned with bond markets, our focus in this paper, are few and far between. Ghosh and Wolf (2000), in the same study noted in Subsection B above, estimate the impact of the basic gravity variables on debt outflows from Germany, the U.S. and Italy to a number of different destinations. Interestingly, these estimates do not appear to fit the data particularly well, except in the case of the United States. Buch (2000b) uses IMF data on debt securities for 1997 only. In her study the basic gravity variables are well behaved and look similar to those in regressions for bank claims. ${ }^{16}$ The impact of having a larger domestic banking system is ambiguous, with the sign of the effect varying by source country). Finally, coefficients on the ratio of bank loans to total debt finance suggest that the relative importance of bond finance rises with the financial development of the host country, while country (population) size is otherwise insignificant, suggesting minimal economies of scale. ${ }^{17}$

Thus, the few previous studies that have utilized the gravity model to study the bond market raise as many questions as they answer. In what follows we therefore see whether we can push this literature forward another step.

\footnotetext{
${ }^{16}$ Suggesting in turn that the relatively poor results in the study by Ghosh and Wolf reflect the very limited nature of their sample.

${ }^{17}$ In the study otherwise closest to our own, Kim, Lee and Shin (2005) use IMF data on total portfolio claims (portfolio equity, debt securities and bank claims) rather than just bonds for 1997 and 2001 through 2004. They find that trade is positively associated with financial integration. When trade variable is added, the dummy variable indicating that both the source and recipient country are in East Asia goes to zero. They also include a variable for whether one of the pair is a global financial center and find that this matters strongly for Asia, as if countries in the region are more heavily linked with global financial centers than with one another.
} 


\section{Data and Specification}

The dependent variable in our analysis is the log of bilateral international portfolio holdings of long-term debt securities from the Coordinated Portfolio Investment Survey (CPIS) compiled by the IMF for the years 2001-2003. ${ }^{18}$ The purpose of the survey is to collect information on the stock of cross-border holdings of equities, long-term debt securities, and short-term debt securities, all valued at market prices and broken down by the economy of residence of the issuer. Central bank reserve holdings are excluded. ${ }^{19}$

To date, the IMF has released five waves of CPIS data. ${ }^{20}$ The first wave was for end1997; 29 economies participated. The second through fourth waves were released annually from end-2001 through end-2003. The number of countries participating tended to rise over time; 69 economies participated in 2003. For each participating economy, the survey reports holdings in all destination economies. The list of reporting economies appears in the appendix. For this study we create an unbalanced panel using data for 2001-2003. ${ }^{21}$

\footnotetext{
${ }^{18}$ To avoid the problem of log of zero, we use natural logs of $(1+$ the variable). The data set and data description are available on the internet at http://www.imf.org/external/np/sta/ pi/cpis.htm.

${ }^{19}$ Thus, our results concerning the determinants of such positions should be understood as reflecting the investment decisions of private agents and, where appropriate, government agencies with foreign holdings. Although central bank reserves are excluded from the CPIS data, it still could be that large reserves are signal that exchange rates will be relatively stable, capital markets will remain open, and liquidity will be ensured through backstopping operations. In the section on sensitivity analysis below, we therefore add reserves in both the sending and receiving countries to our baseline specification.

${ }^{20}$ Since the first draft of this paper was written, the fifth wave of CPIS data has been released, but the amount of information made publicly available, especially at the disaggregated level, is still limited. We prefer to wait for the complete data set before extending our analysis.

${ }^{21}$ We drop the 1997 data since the smaller and less representative sample would likely aggravate problems of selectivity (addressed below).
} 
In designing this survey the IMF has attempted to ensure comprehensiveness and consistency across countries. All national surveys are conducted simultaneously, use consistent definitions, and are structured to encourage the use of best practices in data collection. Specific procedures are recommended to minimize the danger of misclassification and double counting. For example, the issuance of depository receipts creates the potential for double counting since there will then exist two securities that can be reported as held but only one underlying liability. ${ }^{22}$ Depository receipts are therefore recorded by looking through the financial institution that issues the receipts; instead the holder of the receipts are taken to have a claim on the underlying asset. In this case American depository receipts (ADRs) are recorded as liabilities of the non-U.S. enterprise whose securities underlie the ADR issue and not of the U.S. financial institution that issues the ADRs.

Despite all this, there are problems with the CPIS (see also Lane and Milesi-Ferretti 2003). These include (i) incomplete country coverage, as some large holders of portfolio assets, such as China, Saudi Arabia and United Arab Emirates, have not participated in the survey; (ii) under-reporting of assets by CPIS participants due to incomplete institutional coverage; (iii) third party holding, as the survey responses in some countries may be based on custodians instead of end-investors; and (iv) problems with collection methods, especially for those participating in the survey for the first time. The exclusion of China may be consequential for comparisons of Asia with other regions, although we would note that flows

\footnotetext{
${ }^{22}$ Depository receipts are securities that represent ownership of securities held by a depository.
} 
from other Asian countries responding to the survey to China are included in our analysis. ${ }^{23}$

Note that we are unable to analyze separately the determinants of cross-border holdings of corporate bonds and government bonds, since the CPIS reports only data on the sum of the two. ${ }^{24}$ Nor do we have information on the currency composition of bilateral holdings. The years 2001-3, spanned by our survey data, were special ones in international financial markets. The beginning of this period was disturbed by default in Argentina and financial difficulties in Turkey, while its end was dominated by low global interest rates and surging cross-border investment. ${ }^{25}$ It is not clear in what direction these particular conditions might influence our estimates of the coefficients of interest. Still, it will clearly be important to include year fixed effects or to apply equivalent treatments to prevent our results from being contaminated by temporal effects.

Tables 1 and 2 provide summary statistics of the CPIS data by region of source and destination countries. Table 1 shows the average amount of cross-border bond holdings

\footnotetext{
${ }^{23}$ Also, since central bank holdings of foreign bonds are not included in the aggregates analyzed here, as noted above, the fact that China is not included is somewhat less troubling. In addition to China, some readers may also concern about the results because of the exclusion of Indian resident's holdings of foreign debt securities from the sample. According to the IMF's International Investment Position Statistics, India invested US\$300-400 million in foreign portfolio debt securities during the sample period. The exclusion of bond investment from India should affect the results only marginally.

${ }^{24}$ Doing otherwise would violate the IMF's commitment to keep confidential the information it obtains on the composition of individual central banks' foreign reserves, where central banks so require. Other evidence (such as that reported in Eichengreen, Borensztein and Panizza 2006) suggests that the cross-border holdings analyzed here predominantly take the form of government bonds. We are however able, in our companion paper, to analyze the determinants of domestic market capitalization (as opposed to regional and global bond market integration, our focus here) separately for corporate and government bonds.

${ }^{25}$ Note, however, that 2005 and the first quarter of 2006, when emerging market spreads fell to unprecedentedly low levels and enormous volumes of capital flowed into emerging markets as a corollary of the so-called "carry trade," are not included in our sample period.
} 
during the sample period. It is not surprising that the cross-border holdings of long-term debt securities are the highest within the European Union, as the region's financial integration and financial development are relatively more advanced. While Asian countries hold a large sum of foreign bonds issued by countries outside the region, their holdings of bonds issued by countries within the region are relatively small. Latin America, on the other hand, holds only a small position of foreign debt securities, and the intra-regional holdings are smaller than those of Asia. Table 2 shows cross-border bond investment in percent of the total bonds outstanding of the destination region. ${ }^{26}$ In other words, the table shows the share of each region's debt securities outstanding held by foreign investors as reported by the CPIS. The share of intra-regional bond holdings in Asia appears to be smaller than in Latin America because of its larger amount of bonds outstanding.

Our empirical strategy is to estimate the gravity model, augmented by various control variables. Specifically, we estimate the following equation:

$$
\ln \left(\text { bond }_{i j t}\right)=\alpha+\beta_{1} \ln \left(\text { Size }_{i t}\right)+\beta_{2} \ln \left(\text { Size }_{j t}\right)+\beta_{3} \ln \left(\text { distance }_{\mathrm{ij}}\right)+\boldsymbol{\beta}_{\mathrm{w}}^{\prime} \mathbf{w}_{\mathrm{it}}+\boldsymbol{\beta}_{\mathrm{x}}^{\prime} \mathbf{x}_{\mathbf{j t}}+\boldsymbol{\beta}_{\mathrm{z}}^{\prime} \mathbf{z}_{\mathrm{ijt}}+\varepsilon_{i j t}
$$

where $i$ denotes the source; $j$ denotes the destination country of bond investments; and $t$ denotes time, which spans from 2001-2003 in the sample. bond $_{i j t}$ is the cross-border holdings of long term debt securities from country $i$ to country $j$ at time $t . \mathbf{w}_{\mathbf{i t}}$ is a vector of source

\footnotetext{
${ }^{26}$ The total bond outstanding is the sum of domestic and international debt securities from BIS securities debt statistics.
} 
country-specific explanatory variables, $\mathbf{x}_{\mathrm{it}}$ is a vector of destination country-specific explanatory variables, and $\mathbf{z}_{\mathbf{i t}}$ is a vector of bilateral explanatory variables. The descriptions and sources of these explanatory variables are listed in the appendix. Finally, $\varepsilon_{i j t}$ is an error term, which can be specified differently depending on the estimation method. For example, in an OLS model, $\varepsilon_{i j t}$ would be independently and identically distributed $I I D\left(0, \sigma_{\varepsilon}^{2}\right)$. If we assume a destination country fixed effects model, $\varepsilon_{i j t}=u_{j}+v_{i j t}$, where $u_{j}$ is constant for each destination country and $v_{i j t}$ is independently and identically distributed $\operatorname{IID}\left(0, \sigma_{v}^{2}\right)$. In a random effects model, $u_{j}$ would be drawn from $\operatorname{IID}\left(0, \sigma_{u}^{2}\right)$ where $u_{j}$ and all explanatory variables are uncorrelated with $v_{i j t}$.

\section{Basic Results}

To implement the gravity model, we will start with ordinary least squares, then add destination-country random effects and fixed effects (where the latter forces us to eliminate time-invariant recipient country variables), and finally use country-pair fixed effects (forcing us to drop country pair variables that do not vary over time).

As shown in Table 4, the basic gravity variables (country size, log of distance, land border dummy, common language dummy) behave well in our pooled OLS specifications. In Table 5 we add recipient country fixed and random effects. The Breusch-Pagan Lagrange Multiplier (LM) test suggests that that random effects are preferred to pooled OLS, and 
Hausman's specification test prefers fixed effects to random effects. Table 6 reports the baseline results using country-pair random effects model. ${ }^{27}$

We find, similar to results in the literature, that country size matters: larger countries invest more in other countries' bonds; at the same time, larger countries attract more bond investment from other countries. The results are similar whether we measure country size by GDP, land area, or population. Distance between countries enters negatively, consistent with the information-cost hypothesis. The coefficients on the land border dummy are positive but not robust. This implies that contiguity is a less important determinant of information and transaction costs for finance than trade (which makes sense in that physical transportation costs, which are often minimized by contiguity, matter more for the latter).

The interest rate variables highlight the importance of push factors: investments do not always go to the countries with higher interest rates, but they clearly come from countries with lower interest rates. ${ }^{28}$ We find the same when we instead use the average monthly return on home country bonds and the average monthly return on foreign country bonds in home country currency (Table 7). ${ }^{29}$ (We interpret the average monthly return as the

\footnotetext{
${ }^{27}$ Again, the LM test rejects the null hypothesis of pooled OLS. The results with fixed effects are not reported, as we are forced to drop all country-pair, time-invariant variables (e.g. distance, intraregional dummy variables), many of which are of particular interest.

${ }^{28}$ We use the differences between LIBOR rate and domestic interest rates as the independent variables to control for changes in global interest rates. A positive coefficient on LIBOR - source country's interest rate implies that cross-border holdings are higher for source countries with lower interest rates.

${ }^{29}$ We measure past bond returns using total return indices, taking into account changes in bilateral exchange rates by using own-currency returns for source countries and source-country-currency returns for destination countries. For emerging market countries, we use J.P. Morgan's Emerging Market Bond Indices (EMBI) total return indices, which compute total returns (capital gains and interest returns) on U.S. dollar-denominated debt instruments issued by sovereign and quasi-
}

(continued) 
historical or backward-looking return and the interest differential as the contemporaneous or forward-looking return.) These results are consistent with accounts emphasizing the importance of global factors and conditions in the financial centers as determinants of conditions in emerging markets (see e.g. Calvo 1999). They are suggestive for a paper presented in the summer of 2006, since the first half of the year has been marked by substantial flows into emerging market bonds and, in turn, prompted a debate over whether this reflects mainly improved fundamentals in the emerging markets or the low level of interest rates and abundant liquidity in the advanced economies. Our results provide some support for the second interpretation.

The correlation of bond returns enters positively in our equations, which is easier to interpret in terms of return chasing than diversification. ${ }^{30}$ This is the "correlation puzzle" identified by McCauley and Jiang (2004) in their analysis of bank-intermediated flows. McCauley and Jiang (2004) observe that arbitrage has done little to equalize returns between Asian local currency bonds and their industrial-country counterparts, consistent with this

sovereign entities. For mature market countries, we use J.P. Morgan's Government Bond Indices (GBI), which track total returns on local currency government debt instruments. For source countries we calculate returns from its bond index and, if applicable, convert the returns into its own currency. For destination countries we use unhedged bond returns in source country currency to take into account changes in bilateral exchange rate. In principle, it would be desirable to measure the extent of hedging behavior directly, perhaps using data on the existence of level of activity on hedging markets. However, information on activity on such markets, and even on their existence, is available in systematic form only for a relatively small subset of countries.

${ }^{30}$ We compute the correlation of bond returns using 3-year rolling correlation of the past total bond returns (as described earlier). Given expected returns and portfolio weights, the lower the correlation of returns on two assets, the lower the variance of they portfolio they comprise. Hence one would expect a risk adverse investor to choose foreign assets with lower return correlation with their local portfolio in order to diversify and minimize portfolio risks. The positive coefficient on the return correlation implies that investors choose foreign bonds with returns more correlated with their local bond portfolio. 
finding, but they also suggest that this pattern should make diversification attractive; our results suggest that there has been little such diversification to date. This result is also consistent with interpretations of recent trends emphasizing the high level of liquidity in the financial centers in driving flows to emerging markets as well as trend-chasing behavior as opposed to diversification motives. ${ }^{31}$

In contrast to the mixed results in studies of bank loans, for bond markets we consistently find that capital controls are important. ${ }^{32}$ The regressions suggest that controls in both source and destination countries matter in anticipated fashion. Controls on outflows from the investing country always enter with the larger coefficient (in absolute value terms), as if these measures are especially binding. All this is consistent with findings in our earlier paper on the domestic dimension of bond market development - that capital controls are negatively associated with domestic bond-market capitalization.

The volatility of the bilateral exchange rate enters with a strong negative coefficient. ${ }^{33}$ Again, this is consistent with our earlier analysis of domestic bond-market capitalization, where we found that more volatile exchange rates had a negative effect (which we interpreted as evidence that exchange rate volatility discourages foreign participation).

\footnotetext{
${ }^{31} \mathrm{We}$ should note that this result is also consistent with reverse causality, in the sense that larger cross-border investments between two countries could result in higher correlations of domestic and foreign returns.

${ }^{32}$ We use the lines for restrictions on capital transactions in bonds and other debt instruments from the IMF's Annual Report on Exchange Arrangements and Exchange Restrictions. The data are entered as a dummy variable where " 1 " means there is a restriction on capital transactions in bonds and other debt instrument and " 0 " means there is not.

${ }^{33}$ The volatility of the bilateral exchange rate is measured as annual standard deviation of monthly changes of logs of bilateral exchange rates.
} 
Interestingly, when we add the Asia dummy to the preceding specifications, it enters with a positive coefficient, as if Asian bond markets are more integrated, so measured, than a randomly selected pair of bond markets. ${ }^{34}$ But this coefficient goes to zero in Table 8 , where we include financial sector variables (domestic credit provided by the banking sector as a percent of GDP and stock market capitalization as a percent of GDP). When we add an analogous dummy for members of the European Union (as of 2001-3), it is also positive and significant, and the point estimate is even larger. In contrast to Asia, the EU dummy is not wiped out by adding financial sector measures. Thus, cross border participation in Europe appears to reflect more than simply the advanced nature of the region's financial sector and the absence of capital controls; it presumably also reflects the extent of, inter alia, regulatory harmonization. ${ }^{35}$

In Table 9, we add several proxies for the quality of institutions of the destination country. ${ }^{36}$ Not surprisingly, measures of the quality of institutions in the destination country are consistently important in explaining cross-border holdings. Indices measuring law and order, corruption, bureaucratic quality, and the investment risks (higher values mean better

\footnotetext{
${ }^{34}$ The Asia dummy is equal to 1 for Hong Kong SAR, Indonesia, Japan, Korea, Macao SAR, Malaysia, the Philippines, Singapore, Taiwan Province of China, and Thailand. Note that it leaves out Laos, Myanmar, Cambodia, Brunei and Vietnam, for which data are spotty and which do not participate fully in the region's entire range of financial-market initiatives.

${ }^{35}$ The Latin America dummy is opposite in sign. It also tends to lose some of its statistical significance when we add financial sector variables, but not across the board.

${ }^{36}$ While these recipient-country-specific control variables are not time-invariant, the variations over time are small compared to cross-country variations. Results using destination country fixed effects model thus may not be very meaningful. As a result, we will report the results from the random effects model only.
} 
institutions) all tend to enter with positive coefficients. ${ }^{37}$ We similarly obtain a negative coefficient on number of days required to enforce a contract (from Djankov et al. 2005). ${ }^{38}$

Even when we control for institutional quality and interest rates, credit ratings continue to matter. The direction of the effect is plausible: higher ratings mean higher foreign holdings. It may be that the rating agencies are capturing something in addition to the standard measures of institutional quality. Or it could be that restrictive covenants preventing institutional investors from holding bonds of issuers with sub-investment-grade ratings are driving this result.

Interestingly, the intraregional dummy variable for Latin America turns positive and significant when we control for the quality of institutions. The importance of institutional weaknesses for various aspects of bond market development in Latin America has been widely remarked upon. Thus, de la Torre and Schmuker (2004) observe that the high cost of judicial proceedings is a factor discouraging foreign investors from holding the bonds of a number of Latin American countries. Inter-American Development Bank (2005) observes that Latin America fares poorly when rated on both investor and creditor rights. In both cases the highest ranked Latin American country - Chile - has values according to the standard indices that are lower than the Asian average. Eichengreen, Borensztein and

\footnotetext{
${ }^{37}$ An exception is the corruption measure. However, there appears to be strong colinearity between per capita income and the institutional variables (not surprisingly): the sign and significance of the latter are sensitive to whether per capita income is included (since this is associated with other hardto-observe dimensions of the strength of institutions).

${ }^{38}$ The measures of legal origin, which are negative for both English and French law (where Nordic law is the omitted alternative), are hard to reconcile with the standard La Porta et al. (1999) view. Recall that these same variables similarly entered with counterintuitive signs in our earlier study using domestic-capitalization data and that Djankov et al. (2005) also find that these variables do not always have the anticipated effects. The mystery deepens.
} 
Panizza (2006) show that Latin American countries comply less fully with international accounting standards than do their Asian counterparts. What is interesting here is that the low level of financial integration in Latin America is fully (indeed, more than fully) explained by the low quality of institutions.

\section{Sensitivity Checks}

We now provide a series of robustness checks of the results reported above.

- We adjust the standard errors for the fact that a number of our institutional variables do not vary over time by clustering on destination countries. ${ }^{39}$ Clustering increases the standard errors on the institutional variables, as expected, but few of the latter lose their statistical significance. ${ }^{40}$ Overall, the results are very similar to before.

- We check for selectivity, which may be important given that only some 70 source countries (of some 180-plus IMF members) participated in the CPIS surveys. We reestimated the basic equations using a Heckman selectivity correction. From the firststage selection equations, we find, plausibly, that countries participating in the survey are larger, richer and have larger banking systems and stock markets. But even after controlling for these selection criteria, the results remain similar to those obtained before. The results are reported in Table 10.

\footnotetext{
${ }^{39}$ In other words, we assume that observations are independent across destination countries but not necessarily within them.

${ }^{40}$ The results, while not reported, are available on request.
} 
- We experiment with alternative measures of the de facto exchange rate regime.

When we replace exchange rate variability, the measure used above, with dummy variables constructed on the basis of Reinhart and Rogoff's exchange rate regime classification, the results remain basically the same. ${ }^{41}$ We find that pegged exchange rates have positive effects on cross-border bond holdings (compared to floating and managed floating regimes), while regimes of limited flexibility enter with significantly negative signs. ${ }^{42}$ See Table 11.

- We experiment with alternative measures of policies toward the capital account. For example, we substitute the alternative measures of the absence of restrictions on all inflows and outflows as well as the financial openness index kindly made available by Nancy Brune. ${ }^{43}$ Again, the results are largely the same. We then substitute Chinn

\footnotetext{
${ }^{41}$ We use the update through 2003 of the Reinhart and Rogoff de facto classification in Eichengreen and Razo-Garcia (2005). For tractability we reclassify their more detailed classifications into 3 main categories: peg, limited flexibility, and floating/managed floating and assign a dummy variable for each category. Floating/managed floating is the alternative omitted from the regressions.

${ }^{42}$ These results, however, are not robust to the measures of the rate of returns. The coefficients lose their significance when we use historical returns instead of interest rate differential.

${ }^{43}$ The measure of capital openness of all inflows is the sum of five dummy variables, measuring respectively controls on inflows of invisible transactions, controls on inflows of export transactions, controls on inflows pertaining to capital and money market securities, controls on inflows pertaining to credit operations, and controls on inward direct investment. For each component, a value of one means open (no restriction) while zero means closed (restriction in place). The resulting measure ranges from zero to five, where higher values imply more open capital account on inflow transactions. Similarly, the measure of capital openness of all outflows is the sum of four variables: controls on outflows of all transactions mentioned previously, except export transactions. The resulting measure ranges from zero to four, where higher values imply more open capital account on outflow transactions. The financial openness index is the sum of the measures of capital openness of inflows and outflows as well as dummy variables indicating controls on inward direct investment, controls on outward direct investment, controls on real estate transactions, provisions specific to commercial banks, and exchange rate structure (where this last variable takes on a value of zero if country has dual or multiple exchange rates). The resulting index ranges from zero to 12 .
} 
and Ito's (2005) measure of financial openness. ${ }^{44}$ Once again, the results are consistent with before: as expected, financial openness has a positive effect on foreign holdings of portfolio debt securities. Again, see Table 11.

- We add a lagged dependent variable to see whether the patterns we detect are robust to a model that explicitly allows for hysteresis or habit formation. Previous work on the determinants of bilateral trade flows using purely cross section data (e.g. Eichengreen and Irwin 1996) showed that such habit formation can be important in practice. To see whether this holds in the present context, we include the lagged dependent variable to a cross section regression estimated 2003 data $^{45}$ To correct for the bias resulted from adding a lagged dependent variable, we also instrument for the lagged dependent variable by the lagged independent variables using two-stage least square regressions. The results are shown in Table 12. In all specifications, we find that there is a strong evidence for the habit formation. While most other coefficients remain unchanged, the Asia dummy becomes insignificant when we control for bond holdings in the previous year. This suggests that whatever is distinctive about crossborder bond holdings within Asia is persistent over time.

- Although central bank reserves are excluded from the CPIS data, it still could be, as noted above, that large reserves are signal that exchange rates will be relatively

\footnotetext{
${ }^{44}$ A note on calculation of this measure is available at http://web.pdx.edu/ ito/Readme_ kaopen163.pdf

${ }^{45}$ We also add a lagged dependent variable to the panel estimates. However, this may create problems for the consistency of the estimates; hence we prefer to rely on the simple cross section for 2003.
} 
stable, capital markets will remain open, and liquidity will be ensured through backstopping operations. Countries with ample reserves will be more sanguine, intuition suggests, about policies of benign neglect toward outward investment. In the inward investment side, some authors (e.g. Dooley and Garber 2005) have argued that reserves should be thought of as collateral, that high reserve levels make it easier for emerging markets to access foreign financial markets. We therefore add reserves scaled by GDP in the sending and receiving countries to our baseline specification. As shown in the first column of Table 13, the coefficient on the reserves of the sending country is positive and significant; as expected, countries with ample reserves can invest abroad with fewer worries. However, reserves in the receiving country enter negatively, which is inconsistent with the collateral hypothesis.

- We explored further possible interpretations of the coefficient on distance. In Table 13, we also added to the basic framework measures of incoming and outgoing telephone traffic and the cost of telephone calls on the grounds that these tell us something about the information flows that are important in portfolio investment decisions, and that this may be what the distance variable is picking up. These additional variables also enter with the expected signs (positive and negative, respectively) and are strongly significant. But the distance variable is still negative and significant as well. This suggests that distance is picking up something besides information communicated through these channels (e.g. time zone difference described above).

- One possibility is that distance is simply a stand-in for the additional difficulty of investing across time zones. Insofar as claims on countries are traded primarily in 
their own time zones, portfolio managers and others may find it inconvenient to get up in the middle of the night to check market conditions and transact. Those impressed by the ease of obtaining information on far distant markets in the internet age may be inclined toward this alternative interpretation. We therefore experimented with a measure of the number of time zones separating the source and destination markets (see Table 13). When this is substituted for distance in our basic specifications, it is again negative and significant (not surprisingly, insofar as distance and time zone differences are positively correlated). But when we include both distance and time zone differences, the former is still significantly negative, as before, while the latter is not positive and significant. It would appear, in other words that distance is not simply a proxy for time zone differences. The positive coefficient on the latter appears to be capturing a tendency for investors to prefer transactions with countries to their east and west rather than to their north or south, although why this should be the case remains an open question. ${ }^{46}$

\section{Connections with Other Aspects of Financial Development}

In this section we consider further variables and specifications designed to shed light on the impact of other aspects of financial development on bond market integration.

We first ask whether stock and bond markets are substitutes or complements. We start by adding the value of listed companies in the source and destination countries as way

\footnotetext{
${ }^{46}$ In particular, this result is not being driven by the inclusion of the major financial centers (the U.S., UK and Japan in the sample). The results are largely the same when we exclude the U.S. and Japan from the sample (see Table 13).
} 
of capturing the depth of their financial markets. Both variables enter positively (Table 14), but it is the size of stock markets in the source (investing) country that seems to matter. This may indicate that these countries have an active institutional investor community inclined to take positions in the securities issued by foreign countries. We attempt to provide more direct evidence on this below.

We also ask, again following up on our previous work, whether having a large and well-developing banking system encourages or discourages efforts to place bonds with foreign investors. For both the source and destination countries, domestic credit provided by the banking sector as a share of GDP is positive, suggesting that a large and active banking system encourages foreign participation in domestic bond markets. This is the same thing found in our previous study on the size of domestic bond markets. There we suggested a number of reasons why this might be so. Banks are producers of information about conditions in financial markets and about the characteristics of financial instruments that may be particularly valuable to foreign investors. They provide underwriting services for domestic issuers, advising the issuer on the terms and timing of the offer. They provide bridge finance in the period when the marketing of bonds is still underway. They provide distribution channels for government bonds and form an important part of the primary dealer network. Their institutional support may also be conducive to secondary-market liquidity. Finally and most directly, banks owing to their relatively large size can be major issuers of bonds themselves.

Conversely, there is the fear that an inefficient banking system may hinder bond market development and participation and that an imperfectly competitive system, in which banks have significant market power, may allow them to use their incumbency advantage to 
hinder the advance of securitization and disintermediation. ${ }^{47}$ We therefore constructed measures of the concentration of the banking system in both the source and destination countries (as a Herfindahl-Hirschman index of commercial bank assets, using data from Bankscope - thus, a higher value indicates greater concentration). Here measures for both the source and destination countries enter negatively as expected, although the signs and levels of statistical significance are sensitive to what control variables are included. We similarly added the share of bank assets accounted for by public-sector banks as an additional measure of banking sector efficiency. ${ }^{48}$ Again, this enters in the expected fashion (negatively). It suggests interpreting this set of results in terms of the negative impact of a relatively inefficient banking system of various aspects of bond market development, more than in terms of strategic behavior by banks with market power.

While our other results remain unchanged, the negative coefficient on cross-holdings within Latin America now goes to zero even without the addition of measures of the quality of institutions. ${ }^{49}$ Borensztein, Eichengreen and Panizza (2006b) show that Latin America looks better in terms of other dimensions of bond market development when one controls for the underdevelopment of the region's financial system generally. ${ }^{50} \mathrm{We}$ find the same thing

\footnotetext{
${ }^{47}$ They may do so by limiting access to the payment system and by supporting the maintenance of regulations that increase the cost of underwriting and issuance (Schinasi and Smith 1998, Rajan and Zingales 2003, Eichengreen and Luengnaruemitchai 2004).

${ }^{48}$ We compute country-level public bank assets by summing assets of commercial banks with share of public ownership more than 50 percent, using the data from Micco, Panizza and Yañez (2004)

${ }^{49}$ Sometimes we even get a significantly positive, albeit small, coefficient.

${ }^{50}$ Another way of putting the point is that the region's bond markets are underdeveloped for the same reasons that the rest of the region's financial system is underdeveloped (those reasons having to do
} 
here. Note that institutional (and other) factors stunting the development of the banking system do not appear to be what is holding back bond market integration in Asia (the coefficients on the dummy variable for intra-Asian cross holdings is little different than before).

\section{The Composition of the Investor Base}

Another approach to analyzing the importance of institutional factors is to make use of the fact that the CPIS reports data by type of institutional investor (banks, insurance companies and mutual funds). East Asia and other regions are making considerable efforts to cultivate the participation of institutional investors in their bond markets. We can use the CPIS data to analyze the importance of these agents for cross-border investment both within the region and globally.

In Table 15 we run three parallel regressions for the three categories of holders banks, insurance companies and mutual funds - estimating them by seemingly unrelated regression to capitalize on the correlation of disturbance terms across types of holders for given country pairs. These results should be interpreted cautiously, since the sample size is now considerably smaller than before. (There turn out to be a non-negligible number of empty cells when we disaggregate by type of investor.)

For what they are worth, the results show that the basic gravity variables are well behaved (virtually without exception the signs remain the same as before). When we turn to

with the institutional variables that also caused the coefficients for intra-Latin American cross holdings to go to zero in Section 4 above). 
the dummy variables for intra-regional cross holdings, the comparison of Asia and Europe is particularly interesting. For banks, insurance companies and mutual funds alike, we get large positive coefficients for intra-regional positions in bond markets in Europe. In Asia, however, we get a positive coefficient for insurance companies but a strongly negative coefficient for mutual funds. This points to the development and behavior of the mutual fund industry as a potential constraint on bond market development in the region. We want to be careful here and to reiterate the provisional nature of these findings, since we have information on the foreign asset positions of mutual funds for only a limited number of Asian countries. Still, the results appear to make sense; in a number of Asian countries assets under management by insurance companies remain significant larger than those under management by mutual funds. Total assets under management by mutual funds are of roughly the same size relative to GDP in East Asia and Latin America (IMF 2005). Despite the fact that Latin American financial markets are relatively underdeveloped along a number of other dimensions, regulators there have taken aggressive steps to encourage the participation of institutional investors, mutual funds and pension funds in particular. ${ }^{51}$ But, in both regions, cross-border investment by mutual funds continues to be hindered by a dearth of appropriate assets. $^{52}$ Note that the Asian Bond Fund, by creating a set of passively managed index funds of regional bonds, is designed to address precisely this problem. ${ }^{53}$

\footnotetext{
${ }^{51}$ Again, see Borensztein, Eichengreen and Panizza (2006b).

${ }^{52}$ A problem that is compounded by the existence of restrictive covenants that limit the classes of assets in which funds can invest.

${ }^{53}$ As noted above, Asian Bond Fund 2 has two components: a \$1 billion central bank reserve pool to be overseen by professional managers for local bond allocation, and a $\$ 1$ billion index unit designed
} 


\section{Conclusions and Policy Implications}

The development of bond markets can be gauged in a number of ways. In this paper we have concentrated on the international dimension. We used data on the extent to which residents of one country hold the bonds of issuers resident in another as a measure of financial integration or interrelatedness, asking how Asia compares with Europe and Latin America and with the base case in which the purchaser and issuer of the bonds reside in different regions. It is no surprise that Europe is head and shoulders above other regions in terms of financial integration so measured. More interesting is that Asia already seems to have made some progress on this front compared to Latin America and the world as a whole. The contrast with Latin America is largely explained by stronger creditor and investor rights, more expeditious and less costly contract enforcement, and greater transparency that lead to larger and better developed financial systems in Asia, something that is conducive to foreign participation in local markets and to intra-regional cross holdings of Asian bonds generally. Further results based on a limited sample suggest that one factor holding back investment in foreign bonds in East Asia may be limited geographical diversification by mutual funds, in turn reflecting a dearth of appropriate assets. Asian Bond Fund 2, by creating a passively managed portfolio of local currency bonds potentially attractive to mutual fund managers and investors, may help to relax this constraint.

to list on eight stock exchanges beginning with Hong Kong. The regional index is designed to provide a benchmark structure for tracking pan-Asian performance as well as facilitating one-stop entry for retail and institutional buyers in particular. 
We also find evidence that cross-holdings are heavily driven by financial conditions in the investing country, which suggests that bond market conditions could adjust abruptly for reasons having nothing to do with policies in the borrowing economy. Our results also indicate that bondholders are attracted to the securities of countries whose returns co-vary with their own, suggesting return chasing rather than diversification behavior. These are reasons for skepticism that the development of bond markets is a panacea for stabilizing capital flows. 


\section{References}

Aviat, Antonin and Nicolas Coeurdacier (2005), "The Geography of Trade in Goods and Asset Holdings," unpublished manuscript, CNRS-EHESS-PNPC-ENS.

Borensztein, Eduardo, Barry Eichengreen and Ugo Panizza (2006a), "Debt Instruments and Policies for the New Millennium: New Markets and New Opportunities," unpublished manuscript, Inter-American Development Bank (March).

Borensztein, Eduardo, Barry Eichengreen and Ugo Panizza (2006b), "Building Bond Markets in Latin America," unpublished manuscript, Inter-American Development Bank (March).

Buchanan, Michael (2005), "Emerging Markets and the Global Economy - Hysteresis not Hysteria," Global Economics Weekly, Goldman Sachs (30 November).

Buch, Claudia (2000a), "Are Banks Different? Evidence from International Data," Kiel Working Paper no. 1012, Kiel: Kiel Institute of World Economics.

Buch, Claudia (2000b), "Information or Regulation: What is Driving the International Activities of Commercial Banks?" Kiel Working Paper no. 1011, Kiel: Kiel Institute of World Economics.

Calvo, Guillermo (1999), "Contagion in Emerging Markets: When Wall Street is a Carrier," unpublished manuscript, University of Maryland.

Calvo, Guillermo, Leonardo Liederman and Carmen Reinhart (1994), "Capital Inflows and Real Exchange Rate Appreciation in Latin America," IMF Staff Papers 40, pp.108-151.

Chinn, Menzie and Hiro Ito (2005), "What Matters for Financial Development? Capital Controls, Institutions, and Interactions," NBER Working Paper No. 11370, also forthcoming in the Journal of Development Economics.

Coeurdacier, Nicolas and Stephane Guibaud (2005), "International Equity Holdings and Stock Return Correlations: Does Diversification Matter at All for Portfolio Choice?" unpublished manuscript, PSE-ENS-EHESS (July).

De la Torre, Augusto and Sergio Schmukler (2004), Whither Latin American Capital Markets? Washington, D.C.: The World Bank.

Djankov, Simeon, Carlee McLiesh and Andrei Shleifer (2005), "Private Credit in 129 Countries," NBER Working Paper no. 11078 (January). 
Dooley, Michael and Peter Garber (2005), "Is it 1958 or 1968? Three Notes on the Longevity of the Revived Bretton Woods System," Brookings Papers on Economic Activity 1, pp.147187.

Eichengreen, Barry (2005), "Comment: Is it 1958 or 1968? Three Notes on the Longevity of the Revived Bretton Woods System," Brookings Papers on Economic Activity 1, pp.188-193.

Eichengreen, Barry, Eduardo Borensztein and Ugo Panizza (2006), "A Tale of Two Markets: Bond Market Development in Latin America and East Asia," unpublished manuscript, Inter-American Development Bank.

Barry Eichengreen \& Douglas A. Irwin (1996), “The Role of History in Bilateral Trade

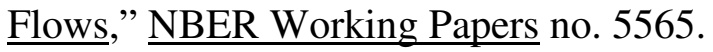

Eichengreen, Barry and Pipat Luengnaruemitchai (2004), "Why Doesn't Asia Have Bigger Bond Markets?" NBER Working Paper no. 10576.

Eichengreen, Barry and Yung Chul Park (2003), "Why Has There Been Less Financial Integration in East Asia than in Europe?" in Yung Chul Park, Takatoshi Ito and Yunjong Wang (eds), A New Financial Market Structure for East Asia, Cheltenham: Edward Elgar, pp.84-103.

Eichengreen, Barry and Raul Razo-Garcia (2005), "The International Monetary System in the Last and Next 20 Years," unpublished manuscript, University of California, Berkeley.

Faruqee, Hamid, Shujing Li and Isabel K. Yan (2004), "The Determinants of International Portfolio Holdings and Home Bias," IMF Working Paper no. WP/04/34 (February).

Ferrucci, Gianluigi (2004), "Understanding Capital Flows to Emerging Market Economies," Financial Stability Review (June), pp.89-97.

Ghosh, Swati and Holger Wolf (2000), "Is There a Curse of Location? Spatial Determinants of Capital Flows to Emerging Markets," in Sebastian Edwards (ed.), Capital Flows and the Emerging Economies, Chicago: University of Chicago Press, pp.137-158.

Goldstein, Morris and Philip Turner (2004), Controlling Currency Mismatches in Emerging Market Economies: An Alternative to the Original Sin Hypothesis, Washington, D.C.: Institute for International Economics.

Inter-American Development Bank (2005), Unlocking Credit: The Quest for Deep and Stable Bank Lending, Washington, D.C.: Inter-American Development Bank.

International Monetary Fund (2005), "Development of Corporate Bond Markets in Emerging Market Economies," Global Financial Stability Report, Washington, D.C.: IMF, pp.103-141. 
Izquierdo, Alejandro, Jacques Morriset and Marcelo Olarreaga (2003), "Information Diffusion in International Markets," Working Paper no. 488, Research Department, Washington, D.C.: Inter-American Development Bank.

Jeanneau, Serge and Marian Micu (2002), "Determinants of International Bank Lending to Emerging Market Countries,” BIS Working Paper no. 112 (June).

Kawai, Masahiro and Li-Gang Liu (2001), "Determinants of International Commercial Bank Loans to Developing Countries," unpublished manuscript, University of Tokyo and Asian Development Bank Institute.

Kim, Soyoung, Jong-Wha Lee and Kwanho Shin (2005), "Regional and Global Financial Integration in East Asia," unpublished manuscript, Korea University.

La Porta, Rafael, Florencio Lopez-de-Silanes, Andre Shleifer and Robert Vishny (1999), "Investor Protection: Origins, Consequences and Reform," NBER Working Paper no.7429 (December).

Lane, Philip R. and Gian Maria Milesi-Ferretti (2004), "International Investment Patterns," Center for Economic Policy Research Discussion Paper no. 4499.

Liu, Li-Gang (2005), "Impact of Financial Services Trade Liberalization on Capital Flows: The Case of China's Banking Sector," unpublished manuscript, Hong Kong Monetary Authority.

Papaioannou, Elias (2005), "What Drives International Bank Flows? Politics, Institutions and Other Determinants," Working Paper no. 437, Frankfurt: ECB.

Martin, Philippe and Helene Rey (2004), "Financial Super-Markets: Size Mattes for Asset Trade," Journal of International Economics 64, pp.335-361.

McCauley, Robert and Guorong Jiang (2004), "Diversifying with Asian Local Currency Bonds," BIS Quarterly Review (September), pp.51-66.

Micco, Alejandro, Ugo Panizza and Mónica Yañez (2004), "Bank Ownership and Performance," IADB Working Paper no. 518.

Portes, Richard and Helene Rey (2005), "The Determinants of Cross-Border Equity Flows," Journal of International Economics 65, pp.269-295.

Rajan, Raghuram and Luigi Zingales (2003), "Banks and Markets: The Changing Character of European Finance,” NBER Working Paper no. 9595.

Reinhart, Carmen M. and Kenneth S. Rogoff (2002), "The Modern History of Exchange Rate Arrangements: A Reinterpretation,” NBER Working Paper no. 8963. 
Rose, Andrew and Mark Spiegel (2004), "A Gravity Model of Sovereign Lending: Trade, Default and Credit," IMF Staff Papers 51 (special issue), pp.50-63.

Schinasi, Gary and Todd Smith (1998), "Fixed Income Markets in the United States, Europe and Japan: Some Lessons for Emerging Markets,” IMF Working Paper no. 98-173. 
Table 1. Average Cross-Border Portfolio Holdings of Long-Term Debt, 2001-2003 (In Millions of US Dollars)

\begin{tabular}{|l|rrrrrr|r|}
\hline $\begin{array}{l}\text { Investments } \\
\text { FromITo }\end{array}$ & \multicolumn{1}{c}{$\begin{array}{c}\text { USA \& } \\
\text { Canada }\end{array}$} & \multicolumn{1}{c}{ Asia } & EU15 & $\begin{array}{c}\text { Eastern } \\
\text { Europe }\end{array}$ & $\begin{array}{c}\text { Latin } \\
\text { America }\end{array}$ & Others & Total \\
\hline USA \& Canada & 12,299 & 51,524 & 326,252 & 6,313 & 65,230 & 250,916 & 712,535 \\
Asia & 444,215 & 41,920 & 527,525 & 3,124 & 10,771 & 254,125 & $1,281,679$ \\
EU15 & 624,247 & 86,538 & $2,914,030$ & 46,689 & 51,621 & 404,261 & $4,127,386$ \\
Eastern Europe & 2,140 & 9 & 6,669 & 1,033 & 46 & 1,028 & 10,926 \\
Latin America & 15,193 & 78 & 2,225 & 22 & 6,999 & 1,161 & 25,678 \\
Others & 260,587 & 19,503 & 324,228 & 3,090 & 14,189 & 76,259 & 697,856 \\
\hline \multirow{2}{*}{ Total } & $1,358,682$ & 199,573 & $4,100,929$ & 60,271 & 148,856 & 987,749 & $6,856,060$ \\
\hline
\end{tabular}

Sources: IMF; Authors' calculation 
Table 2. Average Cross-Border Portfolio Holdings of Long-Term Debt as Percentages of Destination Countries' Total Outstanding Debt Securities

(In Percent)

\begin{tabular}{|l|rrrrrr|}
\hline $\begin{array}{l}\text { Investment } \\
\text { FromlTo }\end{array}$ & $\begin{array}{c}\text { USA \& } \\
\text { Canada }\end{array}$ & \multicolumn{1}{c}{ Asia } & EU15 & $\begin{array}{c}\text { Eastern } \\
\text { Europe }\end{array}$ & $\begin{array}{c}\text { Latin } \\
\text { America }\end{array}$ & \multicolumn{1}{c|}{ Others } \\
\hline USA \& Canada & 0.06 & 0.64 & 2.60 & 2.05 & 7.97 & 9.65 \\
Asia & 2.34 & 0.52 & 4.20 & 1.02 & 1.32 & 9.77 \\
EU15 & 3.29 & 1.07 & 23.18 & 15.20 & 6.31 & 15.54 \\
Eastern Europe & 0.01 & 0.00 & 0.05 & 0.34 & 0.01 & 0.04 \\
Latin America & 0.08 & 0.00 & 0.02 & 0.01 & 0.86 & 0.04 \\
Others & 1.38 & 0.24 & 2.58 & 1.01 & 1.73 & 2.93 \\
\hline Total & 7.17 & 2.48 & 32.62 & 19.62 & 18.20 & 37.98 \\
\hline
\end{tabular}

Sources: IMF; BIS; Authors' calculation 
Table 3. Average Cross-Border Portfolio Holdings of Long-Term Debt, by Sector of Holders, 2001-2003

(In Millions of US Dollars)

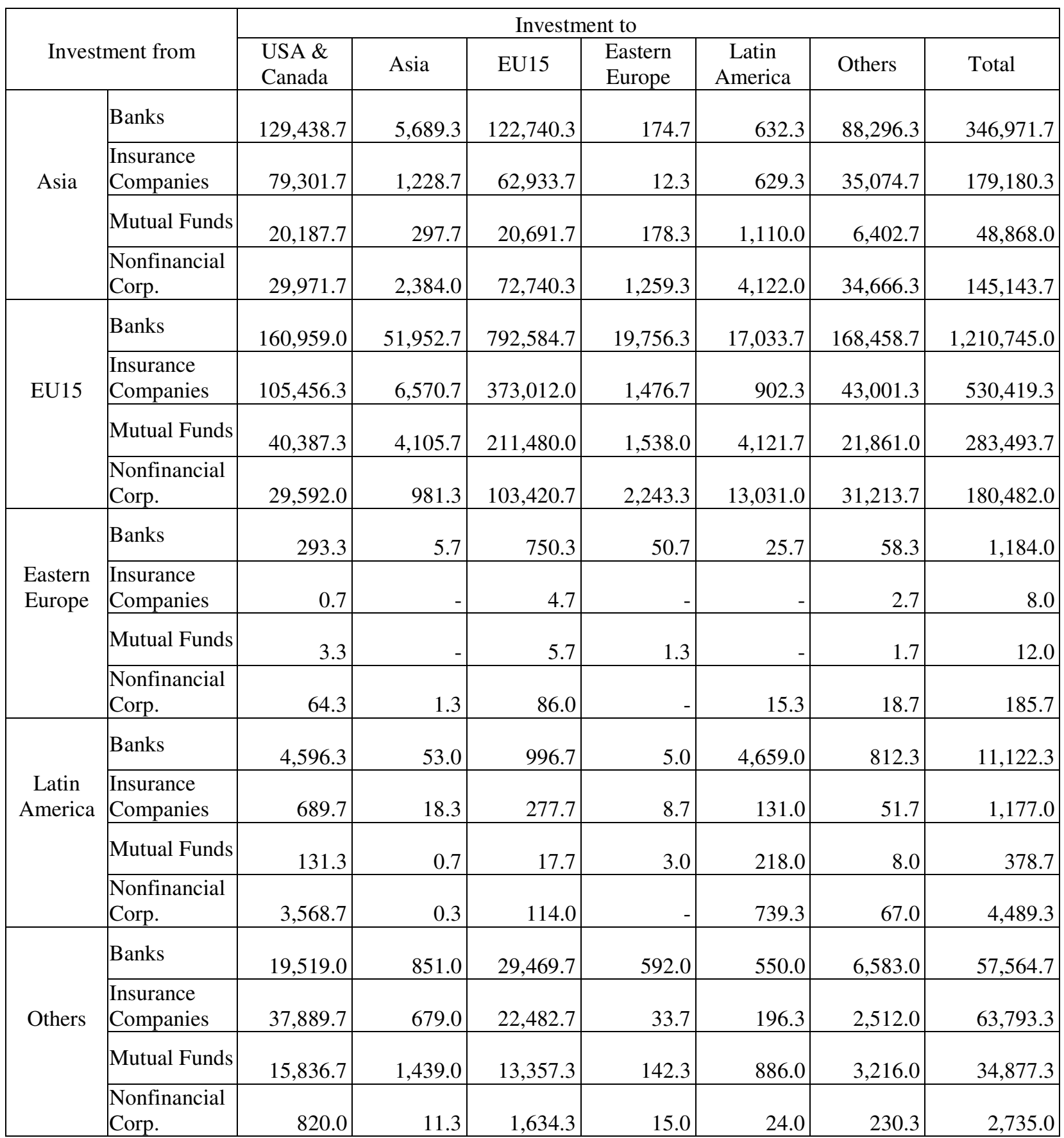

Source: IMF; Authors' calculation. 
Table 4. Baseline Results: Pooled OLS

\begin{tabular}{|c|c|c|c|c|c|}
\hline & $(1)$ & $(2)$ & (3) & (4) & $(5)$ \\
\hline $\log$ of GDP-source country & $\begin{array}{c}0.405 \\
(38.71)^{* * *}\end{array}$ & $\begin{array}{c}0.419 \\
(36.48) * *\end{array}$ & & & $\begin{array}{c}0.307 \\
(27.43) * *\end{array}$ \\
\hline log of GDP-destination country & $\begin{array}{c}0.636 \\
(85.38)^{* *}\end{array}$ & $\begin{array}{c}0.654 \\
(80.27)^{* *}\end{array}$ & & & $\begin{array}{c}0.524 \\
(58.72)^{* *}\end{array}$ \\
\hline $\begin{array}{l}\log \text { of GDP, PPP-source country } \\
\log \text { of GDP, PPP-destination country }\end{array}$ & & & $\begin{array}{c}0.384 \\
(28.15)^{* *} \\
0.666 \\
(67.91)^{* *}\end{array}$ & & \\
\hline log of GDP per capita-source country & & & & $\begin{array}{c}0.900 \\
(34.36)^{* *}\end{array}$ & $\begin{array}{c}0.764 \\
(32.18)^{* *}\end{array}$ \\
\hline $\log$ of GDP per capita-destination country & & & & $\begin{array}{c}0.902 \\
(60.27)^{* *}\end{array}$ & $\begin{array}{c}0.445 \\
(29.22)^{* *}\end{array}$ \\
\hline $\log$ of Distance & $\begin{array}{c}-0.579 \\
(24.47)^{* *}\end{array}$ & $\begin{array}{c}-0.545 \\
(21.24)^{* *}\end{array}$ & $\begin{array}{c}-0.470 \\
(16.90)^{* *}\end{array}$ & $\begin{array}{l}-0.244 \\
(8.99)^{* *}\end{array}$ & $\begin{array}{c}-0.456 \\
(19.16)^{* *}\end{array}$ \\
\hline Land Border Dummy & $\begin{array}{c}0.133 \\
(1.22)\end{array}$ & $\begin{array}{c}0.198 \\
(1.74)\end{array}$ & $\begin{array}{c}0.266 \\
(2.18)^{*}\end{array}$ & $\begin{array}{c}1.277 \\
(10.45)^{* *}\end{array}$ & $\begin{array}{c}0.535 \\
(5.07)^{* *}\end{array}$ \\
\hline Common Language Dummy & $\begin{array}{c}0.415 \\
(8.46)^{* *}\end{array}$ & $\begin{array}{c}0.335 \\
(6.36)^{* *}\end{array}$ & $\begin{array}{c}0.445 \\
(7.74)^{* *}\end{array}$ & $\begin{array}{l}0.151 \\
(2.65)^{* *}\end{array}$ & $\begin{array}{c}0.259 \\
(5.32)^{* *}\end{array}$ \\
\hline Control on bond transactions (inflow) & $\begin{array}{l}-0.359 \\
(9.99)^{* *}\end{array}$ & $\begin{array}{c}-0.411 \\
(10.41)^{* *}\end{array}$ & $\begin{array}{c}-0.654 \\
(15.21)^{* *}\end{array}$ & $\begin{array}{l}-0.009 \\
(0.21)\end{array}$ & $\begin{array}{c}0.012 \\
(8.92)^{* *}\end{array}$ \\
\hline Control on bond transactions (outflow) & $\begin{array}{c}-0.806 \\
(20.15)^{* *}\end{array}$ & $\begin{array}{c}-0.816 \\
(18.56)^{* *}\end{array}$ & $\begin{array}{c}-1.079 \\
(22.42)^{* *}\end{array}$ & $\begin{array}{l}-0.080 \\
(1.48)\end{array}$ & $\begin{array}{l}0.002 \\
(1.51)\end{array}$ \\
\hline LIBOR - Source Country Interest Rate & & $\begin{array}{c}0.020 \\
(14.38)^{* *}\end{array}$ & $\begin{array}{c}0.021 \\
(13.77)^{* *}\end{array}$ & $\begin{array}{c}0.012 \\
(7.93)^{* *}\end{array}$ & $\begin{array}{c}-0.122 \\
(3.19)^{* *}\end{array}$ \\
\hline Destination Country Interest Rate - LIBOR & & $\begin{array}{l}-0.010 \\
(6.85)^{* *}\end{array}$ & $\begin{array}{c}-0.018 \\
(11.09)^{* *}\end{array}$ & $\begin{array}{l}-0.000 \\
(0.04)\end{array}$ & $\begin{array}{c}-0.149 \\
(3.21)^{* *}\end{array}$ \\
\hline Asia & $\begin{array}{c}0.860 \\
(5.72)^{* *}\end{array}$ & $\begin{array}{c}0.643 \\
(4.24)^{* *}\end{array}$ & $\begin{array}{c}0.803 \\
(4.95)^{* *}\end{array}$ & $\begin{array}{c}2.305 \\
(14.19)^{* *}\end{array}$ & $\begin{array}{c}1.112 \\
(7.92)^{* *}\end{array}$ \\
\hline EU15 & $\begin{array}{c}3.808 \\
(43.57)^{* *}\end{array}$ & $\begin{array}{c}3.516 \\
(39.34)^{* *}\end{array}$ & $\begin{array}{c}3.940 \\
(41.43)^{* *}\end{array}$ & $\begin{array}{c}3.683 \\
(38.20)^{* *}\end{array}$ & $\begin{array}{c}3.056 \\
(36.69)^{* *}\end{array}$ \\
\hline Latin America & $\begin{array}{l}-0.279 \\
(2.83)^{* *}\end{array}$ & $\begin{array}{c}0.199 \\
(1.80)\end{array}$ & $\begin{array}{c}0.306 \\
(2.55)^{*}\end{array}$ & $\begin{array}{r}0.187 \\
(1.57)\end{array}$ & $\begin{array}{c}0.407 \\
(3.98)^{* *}\end{array}$ \\
\hline Constant & $\begin{array}{l}-19.034 \\
(50.56)^{* *}\end{array}$ & $\begin{array}{l}-19.694 \\
(48.57)^{* *}\end{array}$ & $\begin{array}{l}-20.157 \\
(41.38)^{* *}\end{array}$ & $\begin{array}{l}-11.876 \\
(31.79)^{* *}\end{array}$ & $\begin{array}{c}-25.709 \\
(63.07)^{* *}\end{array}$ \\
\hline Observations & 12,481 & 10,654 & 10,180 & 10,654 & 10654 \\
\hline R-squared & 0.58 & 0.61 & 0.57 & 0.55 & 0.67 \\
\hline
\end{tabular}

Absolute value of $t$ statistics in parentheses

* significant at 5\%; ** significant at $1 \%$ 
Table 5. Baseline Results: Destination Country Fixed and Random Effects

\begin{tabular}{|c|c|c|c|c|c|c|c|c|c|c|}
\hline & $\begin{array}{l}(1) \\
\mathrm{RE}\end{array}$ & $\begin{array}{l}\text { (2) } \\
\mathrm{FE}\end{array}$ & $\begin{array}{l}\text { (3) } \\
\mathrm{RE}\end{array}$ & $\begin{array}{l}\text { (4) } \\
\text { FE }\end{array}$ & $\begin{array}{l}\text { (5) } \\
\mathrm{RE}\end{array}$ & $\begin{array}{l}\text { (6) } \\
\text { FE }\end{array}$ & $\begin{array}{l}\text { (7) } \\
\mathrm{RE}\end{array}$ & $\begin{array}{l}\text { (8) } \\
\text { FE }\end{array}$ & $\begin{array}{l}\text { (9) } \\
\text { RE }\end{array}$ & $\begin{array}{l}(10) \\
\text { FE }\end{array}$ \\
\hline $\log$ of GDP-source country & $\begin{array}{c}0.428 \\
(45.63)^{* *}\end{array}$ & $\begin{array}{c}0.430 \\
(45.91)^{* *}\end{array}$ & $\begin{array}{c}0.439 \\
(42.10)^{* *}\end{array}$ & $\begin{array}{c}0.440 \\
(42.25)^{* *}\end{array}$ & & & & & $\begin{array}{c}0.317 \\
(30.49)^{* *}\end{array}$ & $\begin{array}{c}0.318 \\
(30.65)^{* *}\end{array}$ \\
\hline $\log$ of GDP-destination country & $\begin{array}{c}0.585 \\
(23.45)^{* *}\end{array}$ & $\begin{array}{c}0.814 \\
(2.04)^{*}\end{array}$ & $\begin{array}{c}0.620 \\
(22.44)^{* *}\end{array}$ & $\begin{array}{l}0.809 \\
(1.75)\end{array}$ & & & & & $\begin{array}{c}0.489 \\
(18.72)^{* *}\end{array}$ & $\begin{array}{l}-0.068 \\
(0.05)\end{array}$ \\
\hline $\begin{array}{l}\log \text { of GDP, PPP-source country } \\
\log \text { of GDP, PPP-destination country }\end{array}$ & & & & & $\begin{array}{c}0.425 \\
(35.36)^{* *} \\
0.633 \\
(20.56)^{* *}\end{array}$ & $\begin{array}{c}0.429 \\
(35.80)^{* *} \\
0.459 \\
(0.97)\end{array}$ & & & & \\
\hline log of GDP per capita-source country & & & & & & & $\begin{array}{c}1.006 \\
(46.06)^{* *}\end{array}$ & $\begin{array}{c}1.014 \\
(46.87)^{* *}\end{array}$ & $\begin{array}{c}0.794 \\
(36.17)^{* *}\end{array}$ & $\begin{array}{c}0.797 \\
(36.36)^{* *}\end{array}$ \\
\hline $\log$ of GDP per capita-destination country & & & & & & & $\begin{array}{c}0.838 \\
(19.81)^{* *}\end{array}$ & $\begin{array}{c}1.328 \\
(2.53)^{*}\end{array}$ & $\begin{array}{c}0.423 \\
(9.89)^{* *}\end{array}$ & $\begin{array}{l}1.068 \\
(0.65)\end{array}$ \\
\hline $\log$ of Distance & $\begin{array}{c}-0.714 \\
(27.65)^{* *}\end{array}$ & $\begin{array}{c}-0.730 \\
(27.84)^{* *}\end{array}$ & $\begin{array}{c}-0.657 \\
(22.87)^{* *}\end{array}$ & $\begin{array}{c}-0.669 \\
(22.87)^{* *}\end{array}$ & $\begin{array}{c}-0.575 \\
(19.09)^{* *}\end{array}$ & $\begin{array}{c}-0.586 \\
(19.15)^{* *}\end{array}$ & $\begin{array}{c}-0.373 \\
(13.47)^{* *}\end{array}$ & $\begin{array}{c}-0.377 \\
(13.45)^{* *}\end{array}$ & $\begin{array}{c}-0.566 \\
(20.98)^{* *}\end{array}$ & $\begin{array}{c}-0.584 \\
(21.09)^{* *}\end{array}$ \\
\hline Land Border Dummy & $\begin{array}{l}-0.098 \\
(0.98)\end{array}$ & $\begin{array}{l}-0.121 \\
(1.22)\end{array}$ & $\begin{array}{l}0.011 \\
(0.11)\end{array}$ & $\begin{array}{l}-0.006 \\
(0.06)\end{array}$ & $\begin{array}{l}0.078 \\
(0.71)\end{array}$ & $\begin{array}{l}0.060 \\
(0.55)\end{array}$ & $\begin{array}{c}0.764 \\
(7.34)^{* * *}\end{array}$ & $\begin{array}{c}0.733 \\
(7.10)^{* *}\end{array}$ & $\begin{array}{c}0.349 \\
(3.50)^{* *}\end{array}$ & $\begin{array}{c}0.323 \\
(3.23)^{* *}\end{array}$ \\
\hline Common Language Dummy & $\begin{array}{c}0.353 \\
(7.50)^{* *}\end{array}$ & $\begin{array}{c}0.348 \\
(7.38)^{* *}\end{array}$ & $\begin{array}{c}0.323 \\
(6.33)^{* *}\end{array}$ & $\begin{array}{c}0.322 \\
(6.27)^{* *}\end{array}$ & $\begin{array}{c}0.403 \\
(7.43)^{* *}\end{array}$ & $\begin{array}{c}0.396 \\
(7.31)^{* *}\end{array}$ & $\begin{array}{c}0.301 \\
(5.94)^{* *}\end{array}$ & $\begin{array}{c}0.323 \\
(6.39)^{* *}\end{array}$ & $\begin{array}{c}0.278 \\
(5.78)^{* *}\end{array}$ & $\begin{array}{c}0.284 \\
(5.87)^{* *}\end{array}$ \\
\hline Control on bond transactions (inflow) & $\begin{array}{l}-0.178 \\
(2.20)^{*}\end{array}$ & $\begin{array}{l}-0.105 \\
(1.01)\end{array}$ & $\begin{array}{c}-0.259 \\
(2.83)^{* *}\end{array}$ & $\begin{array}{l}-0.183 \\
(1.55)\end{array}$ & $\begin{array}{c}-0.351 \\
(3.59)^{* *}\end{array}$ & $\begin{array}{l}-0.132 \\
(0.98)\end{array}$ & $\begin{array}{l}-0.129 \\
(1.43)\end{array}$ & $\begin{array}{l}-0.143 \\
(1.22)\end{array}$ & $\begin{array}{l}-0.144 \\
(1.78)\end{array}$ & $\begin{array}{l}-0.167 \\
(1.48)\end{array}$ \\
\hline Control on bond transactions (outflow) & $\begin{array}{c}-0.874 \\
(24.17)^{* *}\end{array}$ & $\begin{array}{c}-0.877 \\
(24.25)^{* *}\end{array}$ & $\begin{array}{c}-0.870 \\
(21.71)^{* *}\end{array}$ & $\begin{array}{c}-0.872 \\
(21.75)^{* *}\end{array}$ & $\begin{array}{c}-1.219 \\
(28.51)^{* *}\end{array}$ & $\begin{array}{c}-1.230 \\
(28.84)^{* *}\end{array}$ & $\begin{array}{c}-0.143 \\
(3.17)^{* *}\end{array}$ & $\begin{array}{c}-0.149 \\
(3.34)^{* *}\end{array}$ & $\begin{array}{c}-0.147 \\
(3.44)^{* *}\end{array}$ & $\begin{array}{c}-0.147 \\
(3.45)^{* *}\end{array}$ \\
\hline LIBOR - Source Country Interest Rate & & & $\begin{array}{c}0.018 \\
(14.28)^{* *}\end{array}$ & $\begin{array}{c}0.018 \\
(14.17)^{* *}\end{array}$ & $\begin{array}{c}0.019 \\
(14.49)^{* *}\end{array}$ & $\begin{array}{c}0.019 \\
(14.51)^{* *}\end{array}$ & $\begin{array}{c}0.012 \\
(9.03)^{* *}\end{array}$ & $\begin{array}{c}0.012 \\
(9.14)^{* *}\end{array}$ & $\begin{array}{c}0.009 \\
(7.59) * *\end{array}$ & $\begin{array}{c}0.009 \\
(7.33)^{* *}\end{array}$ \\
\hline Destination Country Interest Rate - LIBOR & & & $\begin{array}{l}-0.005 \\
(1.59)\end{array}$ & $\begin{array}{l}-0.001 \\
(0.11)\end{array}$ & $\begin{array}{c}-0.010 \\
(2.91)^{* *}\end{array}$ & $\begin{array}{l}-0.002 \\
(0.37)\end{array}$ & $\begin{array}{l}-0.001 \\
(0.20)\end{array}$ & $\begin{array}{l}0.000 \\
(0.05)\end{array}$ & $\begin{array}{l}0.000 \\
(0.06)\end{array}$ & $\begin{array}{l}-0.000 \\
(0.08)\end{array}$ \\
\hline Asia & $\begin{array}{c}0.932 \\
(6.32)^{* *}\end{array}$ & $\begin{array}{c}0.911 \\
(6.16)^{* *}\end{array}$ & $\begin{array}{c}0.897 \\
(5.95)^{* *}\end{array}$ & $\begin{array}{c}0.893 \\
(5.89)^{* *}\end{array}$ & $\begin{array}{c}1.049 \\
(6.69)^{* *}\end{array}$ & $\begin{array}{c}1.048 \\
(6.66)^{* *}\end{array}$ & $\begin{array}{c}1.910 \\
(12.82)^{* *}\end{array}$ & $\begin{array}{c}1.864 \\
(12.54)^{* *}\end{array}$ & $\begin{array}{c}1.358 \\
(9.54)^{* *}\end{array}$ & $\begin{array}{c}1.351 \\
(9.42)^{* *}\end{array}$ \\
\hline EU15 & $\begin{array}{c}3.183 \\
(36.04)^{* *}\end{array}$ & $\begin{array}{c}3.121 \\
(35.16)^{* *}\end{array}$ & $\begin{array}{c}3.058 \\
(33.49)^{* *}\end{array}$ & $\begin{array}{c}3.010 \\
(32.76)^{* *}\end{array}$ & $\begin{array}{c}3.259 \\
(34.35)^{* *}\end{array}$ & $\begin{array}{c}3.181 \\
(33.41)^{* *}\end{array}$ & $\begin{array}{c}3.115 \\
(34.52)^{* *}\end{array}$ & $\begin{array}{c}3.061 \\
(33.99)^{* *}\end{array}$ & $\begin{array}{c}2.790 \\
(32.37)^{* *}\end{array}$ & $\begin{array}{c}2.746 \\
(31.59)^{* *}\end{array}$ \\
\hline Latin America & $\begin{array}{c}-0.576 \\
(5.85)^{* *}\end{array}$ & $\begin{array}{c}-0.611 \\
(6.16)^{* *}\end{array}$ & $\begin{array}{l}-0.103 \\
(0.93)\end{array}$ & $\begin{array}{l}-0.132 \\
(1.18)\end{array}$ & $\begin{array}{l}-0.025 \\
(0.22)\end{array}$ & $\begin{array}{r}-0.055 \\
(0.47)\end{array}$ & $\begin{array}{l}0.162 \\
(1.47)\end{array}$ & $\begin{array}{l}0.159 \\
(1.44)\end{array}$ & $\begin{array}{c}0.251 \\
(2.39)^{*}\end{array}$ & $\begin{array}{c}0.221 \\
(2.08)^{*}\end{array}$ \\
\hline Constant & $\begin{array}{c}-17.393 \\
(25.91)^{* *}\end{array}$ & $\begin{array}{l}-22.747 \\
(2.37)^{*}\end{array}$ & $\begin{array}{l}-18.636 \\
(24.84)^{* *}\end{array}$ & $\begin{array}{l}-23.137 \\
(2.07)^{*}\end{array}$ & $\begin{array}{l}-19.825 \\
(23.02)^{* *}\end{array}$ & $\begin{array}{c}-15.512 \\
(1.31) \\
\end{array}$ & $\begin{array}{l}-11.431 \\
(23.55)^{* *}\end{array}$ & $\begin{array}{l}-15.261 \\
(3.54)^{* *}\end{array}$ & $\begin{array}{c}-24.345 \\
(38.15)^{* *}\end{array}$ & $\begin{array}{c}-16.008 \\
(0.72)\end{array}$ \\
\hline Observations & 12,481 & 12,481 & 10,654 & 10,654 & 10,180 & 10,180 & 10,654 & 10,654 & 10,654 & 10,654 \\
\hline Number of group (destination countries) & 156 & 156 & 133 & 133 & 129 & 129 & 133 & 133 & 133 & 133 \\
\hline R2-overall & 0.58 & 0.57 & 0.61 & 0.60 & 0.56 & 0.53 & 0.54 & 0.53 & 0.67 & 0.53 \\
\hline R2-within & 0.40 & 0.40 & 0.43 & 0.43 & 0.41 & 0.41 & 0.44 & 0.44 & 0.49 & 0.49 \\
\hline R2-between & 0.74 & 0.74 & 0.79 & 0.78 & 0.70 & 0.69 & 0.62 & 0.62 & 0.86 & 0.53 \\
\hline $\begin{array}{l}\text { Breusch-Pagan LM Test for Random Effects } \\
\text { Prob }>\text { Chi2 }\end{array}$ & $\begin{array}{l}25,192.19 \\
0.00\end{array}$ & & $\begin{array}{c}17,716.94 \\
0.00\end{array}$ & & $\begin{array}{c}25,205.25 \\
0.00\end{array}$ & & $\begin{array}{c}57,638.89 \\
0.00\end{array}$ & & $\begin{array}{c}13,214.07 \\
0.00\end{array}$ & \\
\hline $\begin{array}{l}\text { Hausman Specification Test } \\
\text { Prob }>\text { Chi2 }\end{array}$ & & $\begin{array}{c}49.36 \\
0.00 \\
\end{array}$ & & $\begin{array}{c}22.97 \\
0.03\end{array}$ & & $\begin{array}{c}123.60 \\
0.00\end{array}$ & & $\begin{array}{c}48.81 \\
0.00 \\
\end{array}$ & & $\begin{array}{c}69.50 \\
0.00 \\
\end{array}$ \\
\hline
\end{tabular}

Absolute value of $\mathrm{t}$ statistics in parentheses

$*$ significant at $5 \%$;* significant at $1 \%$ 
Table 6. Baseline Results: Country Pair Random Effects

\begin{tabular}{|c|c|c|c|c|c|}
\hline & (1) & (2) & (3) & (4) & (5) \\
\hline log of GDP-source country & $\begin{array}{c}0.407 \\
(26.44)^{* *}\end{array}$ & $\begin{array}{c}0.438 \\
(26.18)^{* *}\end{array}$ & & & $\begin{array}{c}0.301 \\
(18.10)^{* *}\end{array}$ \\
\hline $\log$ of GDP-destination country & $\begin{array}{c}0.605 \\
(55.29)^{* *}\end{array}$ & $\begin{array}{c}0.622 \\
(52.30)^{* *}\end{array}$ & & & $\begin{array}{c}0.493 \\
(37.61)^{* *}\end{array}$ \\
\hline $\log$ of GDP, PPP-source country & & & $\begin{array}{c}0.378 \\
(19.44)^{* * *}\end{array}$ & & \\
\hline log of GDP, PPP-destination country & & & $\begin{array}{c}0.623 \\
(43.64)^{* *}\end{array}$ & & \\
\hline log of GDP per capita-source country & & & & $\begin{array}{c}0.878 \\
(25.92)^{* *}\end{array}$ & $\begin{array}{c}0.745 \\
(23.31)^{* *}\end{array}$ \\
\hline log of GDP per capita-destination country & & & & $\begin{array}{c}0.826 \\
(41.21)^{* *}\end{array}$ & $\begin{array}{c}0.419 \\
(19.99)^{* *}\end{array}$ \\
\hline $\log$ of Distance & $\begin{array}{c}-0.579 \\
(16.58)^{* * *}\end{array}$ & $\begin{array}{c}-0.604 \\
(16.09)^{* *}\end{array}$ & $\begin{array}{c}-0.558 \\
(13.84)^{* *}\end{array}$ & $\begin{array}{c}-0.292 \\
(7.38)^{* *}\end{array}$ & $\begin{array}{c}-0.479 \\
(13.79)^{* * *}\end{array}$ \\
\hline Land Border Dummy & $\begin{array}{l}0.007 \\
(0.04)\end{array}$ & $\begin{array}{l}-0.037 \\
(0.21)\end{array}$ & $\begin{array}{l}-0.021 \\
(0.11)\end{array}$ & $\begin{array}{c}1.152 \\
(6.17)^{* *}\end{array}$ & $\begin{array}{c}0.408 \\
(2.51)^{*}\end{array}$ \\
\hline Common Language Dummy & $\begin{array}{c}0.467 \\
(6.44)^{* *}\end{array}$ & $\begin{array}{c}0.434 \\
(5.60)^{* *}\end{array}$ & $\begin{array}{c}0.561 \\
(6.64)^{* *}\end{array}$ & $\begin{array}{c}0.180 \\
(2.17)^{*}\end{array}$ & $\begin{array}{c}0.288 \\
(4.03)^{* *}\end{array}$ \\
\hline Control on bond transactions (inflow) & $\begin{array}{c}-0.190 \\
(5.66)^{* *}\end{array}$ & $\begin{array}{c}-0.264 \\
(7.00)^{* *}\end{array}$ & $\begin{array}{c}-0.336 \\
(8.14)^{* *}\end{array}$ & $\begin{array}{c}-0.106 \\
(2.71)^{* *}\end{array}$ & $\begin{array}{c}-0.141 \\
(3.80)^{* *}\end{array}$ \\
\hline Control on bond transactions (outflow) & $\begin{array}{c}-0.488 \\
(12.43)^{* *}\end{array}$ & $\begin{array}{c}-0.518 \\
(12.12)^{* *}\end{array}$ & $\begin{array}{c}-0.574 \\
(12.94) * *\end{array}$ & $\begin{array}{c}-0.197 \\
(4.26)^{* *}\end{array}$ & $\begin{array}{c}-0.225 \\
(5.18)^{* *}\end{array}$ \\
\hline LIBOR - Source Country Interest Rate & & $\begin{array}{c}0.005 \\
(5.32)^{* *}\end{array}$ & $\begin{array}{c}0.005 \\
(5.33)^{* *}\end{array}$ & $\begin{array}{l}0.002 \\
(1.76)\end{array}$ & $\begin{array}{c}0.002 \\
(2.41)^{*}\end{array}$ \\
\hline Destination Country Interest Rate - LIBOR & & $\begin{array}{c}-0.006 \\
(3.86)^{* *}\end{array}$ & $\begin{array}{c}-0.009 \\
(5.87)^{* *}\end{array}$ & $\begin{array}{l}-0.001 \\
(0.68)\end{array}$ & $\begin{array}{l}0.000 \\
(0.09)\end{array}$ \\
\hline Asia & $\begin{array}{c}0.769 \\
(3.27)^{* *}\end{array}$ & $\begin{array}{c}0.581 \\
(2.45)^{*}\end{array}$ & $\begin{array}{c}0.655 \\
(2.57)^{*}\end{array}$ & $\begin{array}{c}2.442 \\
(9.66)^{* *}\end{array}$ & $\begin{array}{c}1.213 \\
(5.52)^{* *}\end{array}$ \\
\hline EU15 & $\begin{array}{c}4.131 \\
(29.60)^{* *}\end{array}$ & $\begin{array}{c}3.846 \\
(26.88) * *\end{array}$ & $\begin{array}{c}4.362 \\
(28.68) * *\end{array}$ & $\begin{array}{c}3.895 \\
(25.39)^{* *}\end{array}$ & $\begin{array}{c}3.254 \\
(24.47)^{* *}\end{array}$ \\
\hline Latin America & $\begin{array}{l}-0.159 \\
(1.10)\end{array}$ & $\begin{array}{l}-0.046 \\
(0.30)\end{array}$ & $\begin{array}{l}-0.077 \\
(0.46)\end{array}$ & $\begin{array}{l}0.043 \\
(0.26)\end{array}$ & $\begin{array}{c}0.313 \\
(2.21)^{*}\end{array}$ \\
\hline Constant & $\begin{array}{c}-18.611 \\
(33.15)^{* *}\end{array}$ & $\begin{array}{c}-19.376 \\
(31.99) * *\end{array}$ & $\begin{array}{c}-18.803 \\
(26.58) * *\end{array}$ & $\begin{array}{c}-10.790 \\
(20.89)^{* *}\end{array}$ & $\begin{array}{c}-24.340 \\
(41.30)^{* *}\end{array}$ \\
\hline $\begin{array}{l}\text { Observations } \\
\text { Number of group (country pair) }\end{array}$ & $\begin{array}{c}12,481 \\
5,166\end{array}$ & $\begin{array}{c}10,654 \\
4,436\end{array}$ & $\begin{array}{c}10,180 \\
4,342\end{array}$ & $\begin{array}{c}10,654 \\
4,436\end{array}$ & $\begin{array}{c}10,654 \\
4,436\end{array}$ \\
\hline R2-overall & 0.58 & 0.61 & 0.55 & 0.55 & 0.67 \\
\hline R2-within & 0.02 & 0.02 & 0.02 & 0.03 & 0.03 \\
\hline R2-between & 0.57 & 0.60 & 0.54 & 0.54 & 0.66 \\
\hline $\begin{array}{l}\text { Breusch-Pagan LM Test for Random Effects } \\
\text { Prob > Chi } 2\end{array}$ & $\begin{array}{c}8,971.53 \\
0.00\end{array}$ & $\begin{array}{c}7,422.27 \\
0.00\end{array}$ & $\begin{array}{c}7,226.88 \\
0.00\end{array}$ & $\begin{array}{c}8,132.88 \\
0.00\end{array}$ & $\begin{array}{c}7,092.55 \\
0.00\end{array}$ \\
\hline
\end{tabular}

Absolute value of $t$ statistics in parentheses

$*$ significant at $5 \%$; ** significant at $1 \%$ 
Table 7. Historical Total Bond Returns vs Interest Rates

\begin{tabular}{|c|c|c|c|c|}
\hline & $\begin{array}{c}(1) \\
\text { Destination } \\
\text { FE }\end{array}$ & $\begin{array}{l}(2) \\
\text { Pair } \\
\text { RE }\end{array}$ & $\begin{array}{c}(3) \\
\text { Destination } \\
\text { FE }\end{array}$ & $\begin{array}{l}(4) \\
\text { Pair } \\
\text { RE }\end{array}$ \\
\hline log of GDP-source country & $\begin{array}{c}0.961 \\
(50.33) * *\end{array}$ & $\begin{array}{c}1.013 \\
(31.05)^{* *}\end{array}$ & $\begin{array}{c}0.976 \\
(45.90)^{* *}\end{array}$ & $\begin{array}{c}1.038 \\
(29.56) * *\end{array}$ \\
\hline $\log$ of GDP-destination country & $\begin{array}{c}2.520 \\
(2.98) * *\end{array}$ & $\begin{array}{c}0.864 \\
(28.28)^{* *}\end{array}$ & $\begin{array}{c}1.996 \\
(2.17)^{*}\end{array}$ & $\begin{array}{c}0.887 \\
(26.15)^{* *}\end{array}$ \\
\hline $\log$ of Distance & $\begin{array}{c}-0.580 \\
(12.30)^{* *}\end{array}$ & $\begin{array}{c}-0.560 \\
(8.75)^{* *}\end{array}$ & $\begin{array}{c}-0.593 \\
(11.53)^{* *}\end{array}$ & $\begin{array}{c}-0.611 \\
(8.90)^{* *}\end{array}$ \\
\hline Land Border Dummy & $\begin{array}{l}-0.146 \\
(1.00)\end{array}$ & $\begin{array}{l}-0.114 \\
(0.47)\end{array}$ & $\begin{array}{l}-0.188 \\
(1.22)\end{array}$ & $\begin{array}{r}-0.237 \\
(0.93)\end{array}$ \\
\hline Common Language Dummy & $\begin{array}{c}0.804 \\
(9.60)^{* *}\end{array}$ & $\begin{array}{c}0.864 \\
(6.69) * *\end{array}$ & $\begin{array}{c}0.805 \\
(9.12)^{* *}\end{array}$ & $\begin{array}{c}0.927 \\
(6.83) * *\end{array}$ \\
\hline Control on bond transactions (inflow) & $\begin{array}{l}-0.184 \\
(0.79)\end{array}$ & $\begin{array}{c}-0.262 \\
(3.62)^{* *}\end{array}$ & $\begin{array}{l}-0.060 \\
(0.20)\end{array}$ & $\begin{array}{c}-0.297 \\
(3.58) * *\end{array}$ \\
\hline Control on bond transactions (outflow) & $\begin{array}{c}-1.624 \\
(25.88)^{* *}\end{array}$ & $\begin{array}{c}-1.129 \\
(15.06)^{* *}\end{array}$ & $\begin{array}{c}-1.589 \\
(23.97)^{* *}\end{array}$ & $\begin{array}{c}-1.107 \\
(14.04)^{* *}\end{array}$ \\
\hline Historical Bond Returns-source country & $\begin{array}{c}-0.094 \\
(4.56)^{* *}\end{array}$ & $\begin{array}{l}-0.013 \\
(1.18)\end{array}$ & & \\
\hline Historical Bond Returns-destination country & $\begin{array}{c}0.043 \\
(2.25)^{*}\end{array}$ & $\begin{array}{l}0.016 \\
(1.77)\end{array}$ & & \\
\hline LIBOR - Source Country Interest Rate & & & $\begin{array}{c}0.006 \\
(2.69)^{* *}\end{array}$ & $\begin{array}{r}-0.002 \\
(0.98)\end{array}$ \\
\hline Destination Country Interest Rate - LIBOR & & & $\begin{array}{l}0.007 \\
(1.07)\end{array}$ & $\begin{array}{l}0.003 \\
(1.17)\end{array}$ \\
\hline Correlation of Bond Returns & $\begin{array}{c}1.598 \\
(11.70)^{* *}\end{array}$ & $\begin{array}{c}0.979 \\
(7.73) * *\end{array}$ & $\begin{array}{c}1.804 \\
(12.19)^{* *}\end{array}$ & $\begin{array}{c}1.154 \\
(8.38)^{* *}\end{array}$ \\
\hline Volatility of Bilateral Exchange Rates & $\begin{array}{c}-0.101 \\
(5.74)^{* *}\end{array}$ & $\begin{array}{l}-0.027 \\
(2.90) * *\end{array}$ & $\begin{array}{c}-0.054 \\
(3.17)^{* *}\end{array}$ & $\begin{array}{l}-0.020 \\
(2.09) *\end{array}$ \\
\hline Asia & $\begin{array}{c}1.416 \\
(7.88)^{* *}\end{array}$ & $\begin{array}{c}0.817 \\
(2.93)^{* *}\end{array}$ & $\begin{array}{c}1.391 \\
(7.58)^{* *}\end{array}$ & $\begin{array}{l}0.710 \\
(2.51)^{*}\end{array}$ \\
\hline EU15 & $\begin{array}{c}1.736 \\
(11.88)^{* *}\end{array}$ & $\begin{array}{c}2.645 \\
(13.19)^{* *}\end{array}$ & $\begin{array}{c}1.642 \\
(10.63)^{* *}\end{array}$ & $\begin{array}{c}2.450 \\
(11.71)^{* *}\end{array}$ \\
\hline Latin America & $\begin{array}{c}-0.930 \\
(4.90)^{* *}\end{array}$ & $\begin{array}{l}-0.661 \\
(2.46)^{*}\end{array}$ & $\begin{array}{c}-0.964 \\
(4.48)^{* *}\end{array}$ & $\begin{array}{c}-0.897 \\
(3.04)^{* *}\end{array}$ \\
\hline Constant & $\begin{array}{l}-82.063 \\
(3.74)^{* *}\end{array}$ & $\begin{array}{c}-41.079 \\
(32.67) * *\end{array}$ & $\begin{array}{l}-69.033 \\
(2.88) * *\end{array}$ & $\begin{array}{c}-41.933 \\
(30.95) * *\end{array}$ \\
\hline Observations & 4,072 & 4,072 & 3,682 & 3,682 \\
\hline Number of Groups & 52 & 1,615 & 47 & 1,461 \\
\hline $\begin{array}{l}\text { R2-overall } \\
\text { R2-within } \\
\text { R2-between }\end{array}$ & $\begin{array}{l}0.52 \\
0.65 \\
0.67\end{array}$ & $\begin{array}{l}0.67 \\
0.04 \\
0.69\end{array}$ & $\begin{array}{l}0.58 \\
0.65 \\
0.68\end{array}$ & $\begin{array}{l}0.67 \\
0.04 \\
0.69\end{array}$ \\
\hline $\begin{array}{l}\text { Hausman Specification Test } \\
\text { Prob }>\text { Chi } 2\end{array}$ & $\begin{array}{c}41.36 \\
0.00\end{array}$ & & $\begin{array}{c}29.79 \\
0.00\end{array}$ & \\
\hline $\begin{array}{l}\text { Breusch-Pagan LM Test for Random Effects } \\
\text { Prob > Chi2 }\end{array}$ & & $\begin{array}{l}2,592.41 \\
0.00\end{array}$ & & $\begin{array}{c}2,309.43 \\
0.00\end{array}$ \\
\hline
\end{tabular}

Absolute value of $\mathrm{t}$ statistics in parentheses

* significant at 5\%; ** significant at $1 \%$ 
Table 8. Development of Financial Sector

\begin{tabular}{|c|c|c|c|c|}
\hline & $\begin{array}{c}(1) \\
\text { Destination } \\
\text { RE }\end{array}$ & $\begin{array}{l}(2) \\
\text { Pair } \\
\text { RE }\end{array}$ & $\begin{array}{c}(3) \\
\text { Destination } \\
\text { RE }\end{array}$ & $\begin{array}{l}(4) \\
\text { Pair } \\
\text { RE }\end{array}$ \\
\hline log of GDP-source country & $\begin{array}{c}0.303 \\
(29.59)^{* *}\end{array}$ & $\begin{array}{c}0.366 \\
(23.36)^{* *}\end{array}$ & $\begin{array}{c}0.387 \\
(28.32)^{* *}\end{array}$ & $\begin{array}{c}0.454 \\
(22.00)^{* *}\end{array}$ \\
\hline $\log$ of GDP-destination country & $\begin{array}{c}0.530 \\
(20.32)^{* *}\end{array}$ & $\begin{array}{c}0.547 \\
(45.33)^{* *}\end{array}$ & $\begin{array}{c}0.676 \\
(15.24)^{* *}\end{array}$ & $\begin{array}{c}0.653 \\
(33.87)^{* *}\end{array}$ \\
\hline $\log$ of Distance & $\begin{array}{c}-0.705 \\
(28.00)^{* *}\end{array}$ & $\begin{array}{c}-0.590 \\
(17.49)^{* *}\end{array}$ & $\begin{array}{c}-0.857 \\
(27.92)^{* *}\end{array}$ & $\begin{array}{c}-0.740 \\
(18.24)^{* *}\end{array}$ \\
\hline Land Border Dummy & $\begin{array}{l}0.107 \\
(1.10)\end{array}$ & $\begin{array}{l}0.115 \\
(0.71)\end{array}$ & $\begin{array}{l}0.027 \\
(0.25)\end{array}$ & $\begin{array}{l}0.048 \\
(0.27)\end{array}$ \\
\hline Common Language Dummy & $\begin{array}{c}0.286 \\
(6.24)^{* *}\end{array}$ & $\begin{array}{c}0.364 \\
(5.19)^{* *}\end{array}$ & $\begin{array}{c}0.331 \\
(5.17)^{* *}\end{array}$ & $\begin{array}{c}0.369 \\
(3.86)^{* *}\end{array}$ \\
\hline Control on bond transactions (inflow) & $\begin{array}{l}-0.166 \\
(2.16)^{*}\end{array}$ & $\begin{array}{c}-0.174 \\
(5.18)^{* *}\end{array}$ & $\begin{array}{l}-0.189 \\
(1.80)\end{array}$ & $\begin{array}{c}-0.231 \\
(4.85)^{* *}\end{array}$ \\
\hline Control on bond transactions (outflow) & $\begin{array}{c}-0.657 \\
(18.10)^{* *}\end{array}$ & $\begin{array}{c}-0.474 \\
(12.01)^{* *}\end{array}$ & $\begin{array}{c}-0.938 \\
(19.98)^{* *}\end{array}$ & $\begin{array}{c}-0.705 \\
(13.36)^{* *}\end{array}$ \\
\hline Size of Banking Sector-source country & $\begin{array}{c}0.009 \\
(29.14)^{* *}\end{array}$ & $\begin{array}{c}0.003 \\
(11.13)^{* *}\end{array}$ & $\begin{array}{c}0.011 \\
(24.99)^{* *}\end{array}$ & $\begin{array}{c}0.005 \\
(11.29)^{* *}\end{array}$ \\
\hline Size of Banking Sector-destination country & $\begin{array}{c}0.006 \\
(5.87)^{* *}\end{array}$ & $\begin{array}{c}0.005 \\
(11.03)^{* *}\end{array}$ & $\begin{array}{c}0.003 \\
(2.60)^{* *}\end{array}$ & $\begin{array}{c}0.003 \\
(5.44)^{* *}\end{array}$ \\
\hline Size of Stock Market-source country & & & $\begin{array}{c}0.008 \\
(20.75)^{* *}\end{array}$ & $\begin{array}{c}0.005 \\
(11.87)^{* *}\end{array}$ \\
\hline Size of Stock Market-destination country & & & $\begin{array}{l}0.001 \\
(1.23)\end{array}$ & $\begin{array}{c}0.001 \\
(3.23)^{* *}\end{array}$ \\
\hline Asia & $\begin{array}{c}0.716 \\
(4.99)^{* *}\end{array}$ & $\begin{array}{c}0.541 \\
(2.39)^{*}\end{array}$ & $\begin{array}{l}0.160 \\
(1.02)\end{array}$ & $\begin{array}{l}0.036 \\
(0.15)\end{array}$ \\
\hline EU15 & $\begin{array}{c}3.110 \\
(36.17)^{* *}\end{array}$ & $\begin{array}{c}3.917 \\
(29.0)^{* *}\end{array}$ & $\begin{array}{c}2.606 \\
(27.65)^{* *}\end{array}$ & $\begin{array}{c}3.357 \\
(22.8)^{* *}\end{array}$ \\
\hline Latin America & $\begin{array}{c}-0.269 \\
(2.80)^{* *}\end{array}$ & $\begin{array}{l}0.036 \\
(0.26)\end{array}$ & $\begin{array}{c}-0.479 \\
(3.35)^{* *}\end{array}$ & $\begin{array}{l}-0.080 \\
(0.42)\end{array}$ \\
\hline Constant & $\begin{array}{c}-14.351 \\
(21.35)^{* *}\end{array}$ & $\begin{array}{c}-16.744 \\
(29.96) * * \\
\end{array}$ & $\begin{array}{c}-19.318 \\
(17.23)^{* *}\end{array}$ & $\begin{array}{c}-20.752 \\
(27.75)^{* *} \\
\end{array}$ \\
\hline $\begin{array}{l}\text { Observations } \\
\text { Number of Groups }\end{array}$ & $\begin{array}{c}12,214 \\
153\end{array}$ & $\begin{array}{c}12,214 \\
5088\end{array}$ & $\begin{array}{c}7,961 \\
96\end{array}$ & $\begin{array}{l}7,961 \\
3499\end{array}$ \\
\hline $\begin{array}{l}\text { R2-overall } \\
\text { R2-within } \\
\text { R2-between }\end{array}$ & $\begin{array}{l}0.62 \\
0.44 \\
0.80 \\
\end{array}$ & $\begin{array}{l}0.61 \\
0.01 \\
0.60 \\
\end{array}$ & $\begin{array}{l}0.63 \\
0.56 \\
0.78 \\
\end{array}$ & $\begin{array}{l}0.62 \\
0.01 \\
0.63 \\
\end{array}$ \\
\hline $\begin{array}{l}\text { Breusch-Pagan LM Test for Random Effects } \\
\text { Prob }>\text { Chi2 }\end{array}$ & $\begin{array}{c}20,862.50 \\
0.00\end{array}$ & $\begin{array}{c}8,336.51 \\
0.00\end{array}$ & $\begin{array}{c}13,797.59 \\
0.00\end{array}$ & $\begin{array}{c}4,952.58 \\
0.00\end{array}$ \\
\hline
\end{tabular}

Number of group(pair)

Absolute value of $t$ statistics in parentheses

$*$ significant at 5\%; ** significant at $1 \%$ 
Table 9. Quality of Institutions: Destination Country Random Effects (usual gravity model variables not reported)

\begin{tabular}{|c|c|c|c|c|c|}
\hline & $(1)$ & $(2)$ & (3) & (4) & $(5)$ \\
\hline $\begin{array}{l}\text { log of GDP per capita-source country } \\
\log \text { of GDP per capita-destination country }\end{array}$ & & $\begin{array}{c}0.872 \\
(27.37)^{* *} \\
0.447 \\
(11.37)^{* *}\end{array}$ & & & \\
\hline Law and order risk & $\begin{array}{c}0.224 \\
(11.21)^{* *}\end{array}$ & $\begin{array}{c}0.163 \\
(8.37)^{* *}\end{array}$ & & $\begin{array}{c}0.195 \\
(6.59)^{* *}\end{array}$ & \\
\hline Corruption risk & $\begin{array}{l}-0.045 \\
(2.13)^{*}\end{array}$ & $\begin{array}{c}-0.214 \\
(9.92)^{* *}\end{array}$ & & $\begin{array}{l}0.021 \\
(0.68)\end{array}$ & \\
\hline Bureaucratic quality & $\begin{array}{c}0.237 \\
(7.71)^{* *}\end{array}$ & $\begin{array}{c}-0.133 \\
(4.05)^{* *}\end{array}$ & & $\begin{array}{c}0.319 \\
(7.09)^{* *}\end{array}$ & \\
\hline Investment profile & $\begin{array}{c}0.148 \\
(10.36)^{* *}\end{array}$ & $\begin{array}{c}0.095 \\
(6.85)^{* *}\end{array}$ & & $\begin{array}{c}0.307 \\
(15.47)^{* *}\end{array}$ & \\
\hline LIBOR - Source Country Interest Rate & & & $\begin{array}{c}0.025 \\
(15.50)^{* *}\end{array}$ & $\begin{array}{c}0.007 \\
(4.25)^{* *}\end{array}$ & \\
\hline Destination Country Interest Rate - LIBOR & & & $\begin{array}{c}0.011 \\
(2.34)^{*}\end{array}$ & $\begin{array}{c}0.009 \\
(1.97)^{*}\end{array}$ & \\
\hline Sovereign Credit Ratings (S\&P) & & & $\begin{array}{c}0.093 \\
(5.49)^{* *}\end{array}$ & $\begin{array}{c}0.109 \\
(6.56)^{* *}\end{array}$ & \\
\hline English legal origin & & & & & $\begin{array}{l}-0.418 \\
(1.17)\end{array}$ \\
\hline French legal origin & & & & & $\begin{array}{l}-0.155 \\
(0.44)\end{array}$ \\
\hline German legal origin & & & & & $\begin{array}{l}-0.208 \\
(0.55)\end{array}$ \\
\hline Socialist legal origin & & & & & $\begin{array}{l}-0.516 \\
(1.28)\end{array}$ \\
\hline Creditor Rights & & & & & $\begin{array}{l}-0.020 \\
(0.33)\end{array}$ \\
\hline Contract Enforcement Days & & & & & $\begin{array}{l}-0.001 \\
(2.09)^{*}\end{array}$ \\
\hline Asia & $\begin{array}{c}1.405 \\
(9.82)^{* *}\end{array}$ & $\begin{array}{c}1.532 \\
(11.06)^{* *}\end{array}$ & $\begin{array}{c}0.811 \\
(4.78)^{* *}\end{array}$ & $\begin{array}{c}1.533 \\
(9.52)^{* *}\end{array}$ & $\begin{array}{c}0.920 \\
(5.96)^{* *}\end{array}$ \\
\hline EU15 & $\begin{array}{c}3.069 \\
(35.97)^{* *}\end{array}$ & $\begin{array}{c}2.917 \\
(35.28)^{* *}\end{array}$ & $\begin{array}{c}2.598 \\
(24.31)^{* *}\end{array}$ & $\begin{array}{c}2.386 \\
(23.72)^{* *}\end{array}$ & $\begin{array}{c}3.164 \\
(33.14)^{* *}\end{array}$ \\
\hline Latin America & $\begin{array}{c}0.403 \\
(3.95)^{* *}\end{array}$ & $\begin{array}{c}0.299 \\
(3.02)^{* *}\end{array}$ & $\begin{array}{l}0.180 \\
(1.31)\end{array}$ & $\begin{array}{c}1.159 \\
(8.59)^{* *}\end{array}$ & $\begin{array}{c}-0.697 \\
(6.04)^{* *}\end{array}$ \\
\hline Constant & $\begin{array}{c}-22.425 \\
(33.81)^{* *} \\
\end{array}$ & $\begin{array}{c}-24.410 \\
(39.90)^{* *}\end{array}$ & $\begin{array}{c}-22.685 \\
(21.77)^{* *}\end{array}$ & $\begin{array}{c}-30.615 \\
(28.89)^{* *}\end{array}$ & $\begin{array}{c}-21.381 \\
(23.13)^{* *}\end{array}$ \\
\hline Observations & 12,343 & 12,343 & 7,159 & 7,048 & 10,420 \\
\hline Number of IFS Country Code 1 & 156 & 156 & 75 & 75 & 121 \\
\hline R2-overall & 0.60 & 0.65 & 0.60 & 0.64 & 0.60 \\
\hline R2-within & 0.44 & 0.47 & 0.49 & 0.56 & 0.42 \\
\hline R2-between & 0.75 & 0.83 & 0.82 & 0.81 & 0.81 \\
\hline $\begin{array}{l}\text { Breusch-Pagan LM Test for Random Effects } \\
\text { Prob }>\text { Chi2 }\end{array}$ & $\begin{array}{c}3,0081.25 \\
0.00\end{array}$ & $\begin{array}{l}19,210.76 \\
0.00\end{array}$ & $\begin{array}{c}5,777.85 \\
0.00\end{array}$ & $\begin{array}{c}8,106.69 \\
0.00\end{array}$ & $\begin{array}{l}13,159.93 \\
0.00\end{array}$ \\
\hline
\end{tabular}

Robust t statistics in parentheses

$*$ significant at $5 \% ; * *$ significant at $1 \%$ 
Table 10. Heckman Selectivity Bias Correction

\begin{tabular}{|c|c|c|c|}
\hline & (1) & (2) & (3) \\
\hline log of GDP-source country & $\begin{array}{c}0.152 \\
(10.39)^{* *}\end{array}$ & $\begin{array}{c}0.232 \\
(18.48)^{* *}\end{array}$ & $\begin{array}{c}0.704 \\
(21.65)^{* *}\end{array}$ \\
\hline log of GDP-destination country & $\begin{array}{c}0.637 \\
(87.98)^{* *}\end{array}$ & $\begin{array}{c}0.637 \\
(87.81)^{* *}\end{array}$ & $\begin{array}{c}0.906 \\
(41.79) * *\end{array}$ \\
\hline log of Distance & $\begin{array}{c}-0.540 \\
(23.57)^{* *}\end{array}$ & $\begin{array}{c}-0.546 \\
(23.72)^{* *}\end{array}$ & $\begin{array}{c}-0.659 \\
(14.59)^{* *}\end{array}$ \\
\hline Land Border Dummy & $\begin{array}{c}0.275 \\
(2.61)^{* *}\end{array}$ & $\begin{array}{c}0.381 \\
(3.63)^{* *}\end{array}$ & $\begin{array}{r}-0.046 \\
(0.29)\end{array}$ \\
\hline Common Language Dummy & $\begin{array}{c}0.401 \\
(8.33)^{* *}\end{array}$ & $\begin{array}{c}0.326 \\
(6.67)^{* *}\end{array}$ & $\begin{array}{c}0.615 \\
(7.10)^{* *}\end{array}$ \\
\hline Control on bond transactions (inflow) & $\begin{array}{c}-0.380 \\
(10.80)^{* *}\end{array}$ & $\begin{array}{c}-0.385 \\
(10.95)^{* *}\end{array}$ & $\begin{array}{c}-0.526 \\
(7.68)^{* *}\end{array}$ \\
\hline Control on bond transactions (outflow) & $\begin{array}{c}-0.430 \\
(10.46)^{* *}\end{array}$ & $\begin{array}{c}-0.458 \\
(11.17)^{* *}\end{array}$ & $\begin{array}{c}-0.825 \\
(10.79)^{* *}\end{array}$ \\
\hline LIBOR - Source Country Interest Rate & & & $\begin{array}{c}0.026 \\
(7.61)^{* *}\end{array}$ \\
\hline Destination Country Interest Rate - LIBOR & & & $\begin{array}{c}0.011 \\
(4.15)^{* *}\end{array}$ \\
\hline Correlation of Bond Returns & & & $\begin{array}{c}1.547 \\
(10.47)^{* * *}\end{array}$ \\
\hline Volatility of Bilateral Exchange Rates & & & $\begin{array}{c}-0.069 \\
(4.13)^{* *}\end{array}$ \\
\hline Asia & $\begin{array}{c}0.968 \\
(6.68) * *\end{array}$ & $\begin{array}{c}0.874 \\
(6.04)^{* *}\end{array}$ & $\begin{array}{c}0.354 \\
(2.07)^{*}\end{array}$ \\
\hline EU15 & $\begin{array}{c}3.607 \\
(41.34)^{* *}\end{array}$ & $\begin{array}{c}3.551 \\
(40.87)^{* *}\end{array}$ & $\begin{array}{c}1.448 \\
(9.53)^{* * *}\end{array}$ \\
\hline Latin America & $\begin{array}{l}-0.035 \\
(0.38)\end{array}$ & $\begin{array}{l}-0.155 \\
(1.53)\end{array}$ & $\begin{array}{l}-0.275 \\
(1.33)\end{array}$ \\
\hline Constant & $\begin{array}{c}-12.308 \\
(26.44)^{* *}\end{array}$ & $\begin{array}{c}-14.431 \\
(34.39)^{* *}\end{array}$ & $\begin{array}{c}-32.144 \\
(28.66)^{* *}\end{array}$ \\
\hline \multicolumn{4}{|l|}{ Selection Equation } \\
\hline log of GDP-source country & $\begin{array}{c}0.404 \\
(80.29)^{* *}\end{array}$ & $\begin{array}{c}0.267 \\
(39.67)^{* *}\end{array}$ & $\begin{array}{c}0.367 \\
(34.14)^{* *}\end{array}$ \\
\hline log of GDP per capita-source country & $\begin{array}{c}0.764 \\
(94.78)^{* *}\end{array}$ & $\begin{array}{c}0.718 \\
(66.70)^{* *}\end{array}$ & $\begin{array}{c}0.673 \\
(46.07)^{* *}\end{array}$ \\
\hline Market Capitalization & & $\begin{array}{c}0.003 \\
(9.97)^{* *}\end{array}$ & $\begin{array}{c}0.007 \\
(13.63)^{* * *}\end{array}$ \\
\hline Domestic Bank Credit & & $\begin{array}{c}0.008 \\
(29.70)^{* *}\end{array}$ & $\begin{array}{c}0.005 \\
(11.58)^{* * *}\end{array}$ \\
\hline Constant & $\begin{array}{c}-16.967 \\
(124.07)^{* *}\end{array}$ & $\begin{array}{c}-13.715 \\
(72.32)^{* *}\end{array}$ & $\begin{array}{c}-16.363 \\
(55.30) * *\end{array}$ \\
\hline Observations & 93,791 & 35,435 & 26,902 \\
\hline
\end{tabular}

Absolute value of $\mathrm{z}$ statistics in parentheses

$*$ significant at 5\%; ** significant at $1 \%$ 
Table 11. Sensitivity Checks: Destination Country Random Effects (usual gravity model variables not reported)

\begin{tabular}{|c|c|c|c|c|c|}
\hline & $(1)$ & $(2)$ & (3) & $(4)$ & $(5)$ \\
\hline Historical Bond Returns-source country & $\begin{array}{c}-0.091 \\
(4.42)^{* *}\end{array}$ & $\begin{array}{c}-0.095 \\
(4.57)^{* *}\end{array}$ & $\begin{array}{c}0.062 \\
(3.03)^{* *}\end{array}$ & $\begin{array}{c}-0.189 \\
(8.26)^{* *}\end{array}$ & $\begin{array}{c}-0.152 \\
(7.43)^{* *}\end{array}$ \\
\hline Historical Bond Returns-destination country & $\begin{array}{l}0.035 \\
(1.90)\end{array}$ & $\begin{array}{l}-0.034 \\
(2.46)^{*}\end{array}$ & $\begin{array}{l}-0.005 \\
(0.37)\end{array}$ & $\begin{array}{c}-0.096 \\
(6.30)^{* *}\end{array}$ & $\begin{array}{c}-0.041 \\
(2.94)^{* *}\end{array}$ \\
\hline Correlation of Bond Returns & $\begin{array}{c}1.588 \\
(11.62)^{* *}\end{array}$ & $\begin{array}{c}1.713 \\
(12.64)^{* *}\end{array}$ & $\begin{array}{c}1.511 \\
(11.81)^{* *}\end{array}$ & $\begin{array}{c}1.348 \\
(9.01)^{* *}\end{array}$ & $\begin{array}{c}1.782 \\
(13.15)^{* *}\end{array}$ \\
\hline Volatility of Bilateral Exchange Rates & $\begin{array}{c}-0.100 \\
(5.82)^{* *}\end{array}$ & & & & \\
\hline Pegged Exchange Rate Regime (Reinhart-Rogoff) & & $\begin{array}{l}0.197 \\
(1.06)\end{array}$ & $\begin{array}{l}0.206 \\
(1.13)\end{array}$ & $\begin{array}{l}0.033 \\
(0.17)\end{array}$ & $\begin{array}{l}0.210 \\
(1.12)\end{array}$ \\
\hline Limited Flexibility (Reinhart-Rogoff) & & $\begin{array}{l}-0.259 \\
(1.66)\end{array}$ & $\begin{array}{l}-0.195 \\
(1.31)\end{array}$ & $\begin{array}{l}-0.385 \\
(2.27)^{*}\end{array}$ & $\begin{array}{l}-0.235 \\
(1.49)\end{array}$ \\
\hline Control on bond transactions (inflow) & $\begin{array}{l}-0.340 \\
(2.14)^{*}\end{array}$ & $\begin{array}{l}-0.159 \\
(0.97)\end{array}$ & & & \\
\hline Control on bond transactions (outflow) & $\begin{array}{c}-1.618 \\
(25.72)^{* *}\end{array}$ & $\begin{array}{c}-1.639 \\
(25.98)^{* *}\end{array}$ & & & \\
\hline NB_capital openness_-inflow & & & $\begin{array}{c}0.092 \\
(2.26)^{*}\end{array}$ & & \\
\hline NB_capital openness_-outflow & & & $\begin{array}{l}-0.085 \\
(2.14)^{*}\end{array}$ & & \\
\hline NB_financial openness index-destination country & & & $\begin{array}{c}0.340 \\
(20.71)^{* *}\end{array}$ & & \\
\hline Chinn-Ito Capital Control-destination country & & & & $\begin{array}{c}0.158 \\
(2.74)^{* *}\end{array}$ & \\
\hline share of last 5 years with capital controls on bond inflow & & & & & $\begin{array}{l}-0.320 \\
(1.53)\end{array}$ \\
\hline share of last 5 years with capital controls on bond outflow & & & & & $\begin{array}{c}-1.999 \\
(26.42)^{* *}\end{array}$ \\
\hline Dummy for IMF program-destination country & $\begin{array}{l}0.105 \\
(0.60)\end{array}$ & $\begin{array}{l}0.064 \\
(0.36)\end{array}$ & $\begin{array}{l}0.111 \\
(0.65)\end{array}$ & $\begin{array}{l}0.187 \\
(0.91)\end{array}$ & $\begin{array}{l}0.055 \\
(0.31)\end{array}$ \\
\hline Asia & $\begin{array}{c}1.380 \\
(7.74)^{* *}\end{array}$ & $\begin{array}{c}1.434 \\
(8.03)^{* *}\end{array}$ & $\begin{array}{c}1.800 \\
(10.55)^{* *}\end{array}$ & $\begin{array}{c}0.853 \\
(4.40)^{* *}\end{array}$ & $\begin{array}{c}1.594 \\
(8.90)^{* *}\end{array}$ \\
\hline EU15 & $\begin{array}{c}1.769 \\
(12.15)^{* *}\end{array}$ & $\begin{array}{c}1.817 \\
(12.46)^{* *}\end{array}$ & $\begin{array}{c}1.557 \\
(11.19)^{* *}\end{array}$ & $\begin{array}{c}2.348 \\
(14.55)^{* *}\end{array}$ & $\begin{array}{c}1.479 \\
(10.01)^{* *}\end{array}$ \\
\hline Latin America & $\begin{array}{c}-0.845 \\
(4.50)^{* *}\end{array}$ & $\begin{array}{c}-0.956 \\
(5.09)^{* *}\end{array}$ & $\begin{array}{c}-0.927 \\
(5.17)^{* *}\end{array}$ & $\begin{array}{c}-1.271 \\
(6.21)^{* *}\end{array}$ & $\begin{array}{c}-0.743 \\
(3.94)^{* *}\end{array}$ \\
\hline Constant & $\begin{array}{c}-39.256 \\
(20.43)^{* *}\end{array}$ & $\begin{array}{c}-38.902 \\
(19.23)^{* *}\end{array}$ & $\begin{array}{c}-42.633 \\
(21.54)^{* *}\end{array}$ & $\begin{array}{c}-38.632 \\
(18.43)^{* *}\end{array}$ & $\begin{array}{c}-35.946 \\
(17.33)^{* *}\end{array}$ \\
\hline Observations & 4072 & 4072 & 4072 & 3876 & 4072 \\
\hline Number of IFS Country Code 1 & 52 & 52 & 52 & 49 & 52 \\
\hline R2-overall & 0.67 & 0.68 & 0.70 & 0.64 & 0.68 \\
\hline R2-within & 0.65 & 0.65 & 0.69 & 0.59 & 0.65 \\
\hline R2-between & 0.71 & 0.73 & 0.73 & 0.77 & 0.73 \\
\hline $\begin{array}{l}\text { Breusch-Pagan LM Test for Random Effects } \\
\text { Prob }>\text { Chi2 }\end{array}$ & $\begin{array}{c}4,886.47 \\
0.00\end{array}$ & $\begin{array}{c}4,275.74 \\
0.00\end{array}$ & $\begin{array}{c}5,183.11 \\
0.00\end{array}$ & $\begin{array}{c}2,315.52 \\
0.00\end{array}$ & $\begin{array}{c}4,485.49 \\
0.00\end{array}$ \\
\hline
\end{tabular}

Absolute value of $\mathrm{z}$ statistics in parentheses

* significant at $5 \%$; * significant at $1 \%$ 
Table 12. Sensitivity Checks: Lagged Dependent Variable

\begin{tabular}{|c|c|c|c|c|c|}
\hline & $\begin{array}{c}(1) \\
\text { OLS }\end{array}$ & $\begin{array}{l}(2) \\
\mathrm{RE}\end{array}$ & $\begin{array}{l}(3) \\
\text { IV }\end{array}$ & $\begin{array}{c}(4) \\
\text { OLS }\end{array}$ & $\begin{array}{l}(5) \\
\text { IV }\end{array}$ \\
\hline Lagged Dependent Variable & $\begin{array}{c}0.942 \\
(130.96)^{* *}\end{array}$ & $\begin{array}{c}0.931 \\
(126.05)^{* *}\end{array}$ & $\begin{array}{c}1.061 \\
(24.06)^{* *}\end{array}$ & $\begin{array}{c}0.899 \\
(71.26)^{* *}\end{array}$ & $\begin{array}{c}0.975 \\
(24.04)^{* *}\end{array}$ \\
\hline log of GDP-source country & $\begin{array}{l}-0.005 \\
(0.49)\end{array}$ & $\begin{array}{l}0.001 \\
(0.07)\end{array}$ & $\begin{array}{c}-0.056 \\
(2.63)^{* *}\end{array}$ & $\begin{array}{c}0.066 \\
(3.22)^{* *}\end{array}$ & $\begin{array}{l}0.001 \\
(0.03)\end{array}$ \\
\hline log of GDP-destination country & $\begin{array}{c}0.078 \\
(9.95)^{* *}\end{array}$ & $\begin{array}{c}0.086 \\
(9.57)^{* *}\end{array}$ & $\begin{array}{l}-0.003 \\
(0.09)\end{array}$ & $\begin{array}{c}0.119 \\
(6.01)^{* *}\end{array}$ & $\begin{array}{l}0.053 \\
(1.33)\end{array}$ \\
\hline Log of Distance & $\begin{array}{c}-0.121 \\
(6.12)^{* *}\end{array}$ & $\begin{array}{c}-0.126 \\
(5.98)^{* *}\end{array}$ & $\begin{array}{l}-0.063 \\
(2.12)^{*}\end{array}$ & $\begin{array}{c}-0.218 \\
(5.99)^{* *}\end{array}$ & $\begin{array}{c}-0.194 \\
(5.01)^{* *}\end{array}$ \\
\hline Land Border Dummy & $\begin{array}{l}-0.171 \\
(2.07)^{*}\end{array}$ & $\begin{array}{l}-0.168 \\
(2.05)^{*}\end{array}$ & $\begin{array}{l}-0.222 \\
(2.51)^{*}\end{array}$ & $\begin{array}{c}-0.380 \\
(3.00)^{* *}\end{array}$ & $\begin{array}{c}-0.407 \\
(3.15)^{* *}\end{array}$ \\
\hline 1 for Common Language & $\begin{array}{l}-0.044 \\
(1.12)\end{array}$ & $\begin{array}{l}-0.027 \\
(0.69)\end{array}$ & $\begin{array}{l}-0.082 \\
(1.90)\end{array}$ & $\begin{array}{l}-0.017 \\
(0.25)\end{array}$ & $\begin{array}{l}-0.064 \\
(0.88)\end{array}$ \\
\hline LIBOR - Source Country Interest Rate & $\begin{array}{c}0.011 \\
(4.90)^{* *}\end{array}$ & $\begin{array}{c}0.012 \\
(5.21)^{* *}\end{array}$ & $\begin{array}{l}0.005 \\
(1.52)\end{array}$ & & \\
\hline Destination Country Interest Rate - LIBOR & $\begin{array}{l}-0.001 \\
(0.97)\end{array}$ & $\begin{array}{l}-0.002 \\
(1.11)\end{array}$ & $\begin{array}{l}0.001 \\
(0.64)\end{array}$ & & \\
\hline control on bond or other debt instruments (inflow) & $\begin{array}{l}-0.036 \\
(1.19)\end{array}$ & $\begin{array}{l}-0.042 \\
(1.14)\end{array}$ & $\begin{array}{l}0.022 \\
(0.58)\end{array}$ & $\begin{array}{l}0.006 \\
(0.10)\end{array}$ & $\begin{array}{l}0.032 \\
(0.55)\end{array}$ \\
\hline control on bond or other debt instruments (outflow) & $\begin{array}{c}-0.122 \\
(3.13)^{* *}\end{array}$ & $\begin{array}{c}-0.129 \\
(3.37)^{* *}\end{array}$ & $\begin{array}{l}-0.038 \\
(0.76)\end{array}$ & $\begin{array}{c}-0.270 \\
(4.35)^{* *}\end{array}$ & $\begin{array}{l}-0.150 \\
(1.71)\end{array}$ \\
\hline Historical Bond Returns-source country & & & & $\begin{array}{c}-0.083 \\
(2.78)^{* *}\end{array}$ & $\begin{array}{l}-0.055 \\
(1.64)\end{array}$ \\
\hline Historical Bond Returns-destination country & & & & $\begin{array}{c}0.066 \\
(3.55)^{* *}\end{array}$ & $\begin{array}{c}0.054 \\
(2.71)^{* *}\end{array}$ \\
\hline Correlation of Bond Returns & & & & $\begin{array}{c}0.236 \\
(2.01)^{*}\end{array}$ & $\begin{array}{l}0.170 \\
(1.37)\end{array}$ \\
\hline Volatility of Bilateral Exchange Rates & & & & $\begin{array}{l}-0.019 \\
(1.02)\end{array}$ & $\begin{array}{l}-0.008 \\
(0.40)\end{array}$ \\
\hline Asia & $\begin{array}{l}-0.133 \\
(1.24)\end{array}$ & $\begin{array}{l}-0.099 \\
(0.90)\end{array}$ & $\begin{array}{l}-0.198 \\
(1.73)\end{array}$ & $\begin{array}{l}-0.206 \\
(1.50)\end{array}$ & $\begin{array}{l}-0.261 \\
(1.83)\end{array}$ \\
\hline EU15 & $\begin{array}{c}0.149 \\
(2.22)^{*}\end{array}$ & $\begin{array}{c}0.158 \\
(2.27)^{*}\end{array}$ & $\begin{array}{l}-0.249 \\
(1.54)\end{array}$ & $\begin{array}{l}-0.012 \\
(0.09)\end{array}$ & $\begin{array}{l}-0.188 \\
(1.21)\end{array}$ \\
\hline Latin America & $\begin{array}{l}0.158 \\
(1.72)\end{array}$ & $\begin{array}{l}0.106 \\
(1.13)\end{array}$ & $\begin{array}{l}0.173 \\
(1.80)\end{array}$ & $\begin{array}{l}0.002 \\
(0.01)\end{array}$ & $\begin{array}{l}-0.021 \\
(0.13)\end{array}$ \\
\hline Constant & $\begin{array}{l}-0.313 \\
(0.92) \\
\end{array}$ & $\begin{array}{r}-0.578 \\
(1.61) \\
\end{array}$ & $\begin{array}{c}2.152 \\
(2.21)^{*}\end{array}$ & $\begin{array}{c}-2.296 \\
(2.76)^{* *}\end{array}$ & $\begin{array}{l}0.642 \\
(0.38) \\
\end{array}$ \\
\hline Observations & 3014 & 3014 & 3014 & 1241 & 1241 \\
\hline $\begin{array}{l}\text { R-squared } \\
\text { Number of Destination countries }\end{array}$ & 0.95 & 129 & 0.94 & 0.94 & 0.94 \\
\hline
\end{tabular}

Absolute value of $\mathrm{t}$ statistics in parentheses

$*$ significant at $5 \% ; * *$ significant at $1 \%$ 
Table 13. Sensitivity Check: Reserves, Distance, Time Zone, and Information costs

\begin{tabular}{|c|c|c|c|c|c|}
\hline & $\begin{array}{c}\text { (1) } \\
\text { Full } \\
\text { Sample }\end{array}$ & $\begin{array}{c}(2) \\
\text { Full } \\
\text { Sample }\end{array}$ & $\begin{array}{c}(3) \\
\text { Full } \\
\text { Sample }\end{array}$ & $\begin{array}{c}(4) \\
\text { Exclude } \\
\text { US and } \\
\text { Japan }\end{array}$ & $\begin{array}{c}\text { (5) } \\
\text { Full } \\
\text { Sample }\end{array}$ \\
\hline $\log$ of GDP-source country & $\begin{array}{c}0.473 \\
(21.41)^{* *}\end{array}$ & $\begin{array}{c}0.385 \\
(33.25)^{* *}\end{array}$ & $\begin{array}{c}0.416 \\
(36.39)^{* * *}\end{array}$ & $\begin{array}{c}0.336 \\
(27.80)^{* *}\end{array}$ & $\begin{array}{c}0.669 \\
(36.15)^{* *}\end{array}$ \\
\hline $\log$ of GDP-destination country & $\begin{array}{c}0.663 \\
(44.35)^{* *}\end{array}$ & $\begin{array}{c}0.653 \\
(78.30)^{* *}\end{array}$ & $\begin{array}{c}0.647 \\
(79.24)^{* * *}\end{array}$ & $\begin{array}{c}0.624 \\
(76.00)^{* *}\end{array}$ & $\begin{array}{c}0.577 \\
(15.92)^{* *}\end{array}$ \\
\hline Log of Distance & $\begin{array}{c}-0.629 \\
(13.50)^{* * *}\end{array}$ & & $\begin{array}{c}-0.778 \\
(21.55)^{* *}\end{array}$ & $\begin{array}{c}-0.779 \\
(21.88)^{* *}\end{array}$ & $\begin{array}{c}-0.537 \\
(12.41)^{* *}\end{array}$ \\
\hline Time Zone Difference & & $\begin{array}{c}-0.050 \\
(8.40)^{* *}\end{array}$ & $\begin{array}{c}0.075 \\
(9.13)^{* *}\end{array}$ & $\begin{array}{c}0.082 \\
(9.89)^{* *}\end{array}$ & \\
\hline phone traffic & & & & & $\begin{array}{c}0.000 \\
(9.75)^{* *}\end{array}$ \\
\hline phone cost & & & & & $\begin{array}{c}-0.548 \\
(11.24)^{* *}\end{array}$ \\
\hline Land Border Dummy & $\begin{array}{l}0.123 \\
(0.62)\end{array}$ & $\begin{array}{c}0.955 \\
(8.76)^{* *}\end{array}$ & $\begin{array}{l}0.019 \\
(0.17)\end{array}$ & $\begin{array}{l}-0.010 \\
(0.09)\end{array}$ & $\begin{array}{l}-0.004 \\
(0.02)\end{array}$ \\
\hline 1 for Common Language & $\begin{array}{c}0.259 \\
(2.73)^{* *}\end{array}$ & $\begin{array}{c}0.241 \\
(4.52)^{* *}\end{array}$ & $\begin{array}{c}0.343 \\
(6.54)^{* *}\end{array}$ & $\begin{array}{c}0.274 \\
(5.19)^{* *}\end{array}$ & $\begin{array}{c}0.647 \\
(7.04)^{* *}\end{array}$ \\
\hline LIBOR - Source Country Interest Rate & $\begin{array}{c}0.047 \\
(10.80)^{* *}\end{array}$ & $\begin{array}{c}0.024 \\
(16.82)^{* *}\end{array}$ & $\begin{array}{c}0.020 \\
(13.97)^{* *}\end{array}$ & $\begin{array}{c}0.019 \\
(13.99)^{* *}\end{array}$ & $\begin{array}{c}0.034 \\
(15.73)^{* *}\end{array}$ \\
\hline Destination Country Interest Rate - LIBOR & $\begin{array}{c}-0.017 \\
(5.65)^{* *}\end{array}$ & $\begin{array}{c}-0.014 \\
(9.60)^{* *}\end{array}$ & $\begin{array}{c}-0.008 \\
(5.28)^{* *}\end{array}$ & $\begin{array}{c}-0.007 \\
(4.90)^{* *}\end{array}$ & $\begin{array}{c}0.014 \\
(4.48)^{* *}\end{array}$ \\
\hline control on bond or other debt instruments (inflow) & $\begin{array}{c}-0.433 \\
(6.11)^{* *}\end{array}$ & $\begin{array}{c}-0.453 \\
(11.28)^{* *}\end{array}$ & $\begin{array}{c}-0.406 \\
(10.31)^{* * *}\end{array}$ & $\begin{array}{c}-0.417 \\
(10.71)^{* *}\end{array}$ & $\begin{array}{l}-0.121 \\
(1.37)\end{array}$ \\
\hline control on bond or other debt instruments (outflow) & $\begin{array}{c}-0.946 \\
(10.09)^{* *}\end{array}$ & $\begin{array}{c}-0.914 \\
(20.55)^{* *}\end{array}$ & $\begin{array}{c}-0.807 \\
(18.41)^{* *}\end{array}$ & $\begin{array}{c}-0.760 \\
(17.70)^{* *}\end{array}$ & $\begin{array}{c}-1.505 \\
(21.38)^{* *}\end{array}$ \\
\hline Reserves/GDP - source country & $\begin{array}{c}2.186 \\
(8.36)^{* *}\end{array}$ & & & & \\
\hline Reserves/GDP - destination country & $\begin{array}{c}-0.785 \\
(3.56)^{* *}\end{array}$ & & & & \\
\hline Asia & $\begin{array}{l}-0.044 \\
(0.16)\end{array}$ & $\begin{array}{c}0.937 \\
(6.07)^{* *}\end{array}$ & $\begin{array}{c}0.745 \\
(4.92)^{* *}\end{array}$ & $\begin{array}{c}1.137 \\
(7.31)^{* *}\end{array}$ & $\begin{array}{c}0.845 \\
(4.27)^{* *}\end{array}$ \\
\hline EU15 & $\begin{array}{c}3.555 \\
(22.29)^{* *}\end{array}$ & $\begin{array}{c}4.047 \\
(46.47)^{* *}\end{array}$ & $\begin{array}{c}3.492 \\
(39.21)^{* *}\end{array}$ & $\begin{array}{c}3.653 \\
(41.94)^{* *}\end{array}$ & $\begin{array}{c}2.867 \\
(25.18)^{* *}\end{array}$ \\
\hline Latin America & $\begin{array}{l}0.101 \\
(0.51)\end{array}$ & $\begin{array}{c}0.463 \\
(4.13)^{* *}\end{array}$ & $\begin{array}{c}0.257 \\
(2.34)^{*}\end{array}$ & $\begin{array}{c}0.225 \\
(2.09)^{*}\end{array}$ & $\begin{array}{c}0.472 \\
(2.21)^{*}\end{array}$ \\
\hline Constant & $\begin{array}{c}-20.389 \\
(27.10) * *\end{array}$ & $\begin{array}{c}-22.934 \\
(58.51)^{* *}\end{array}$ & $\begin{array}{c}-17.898 \\
(39.84) * *\end{array}$ & $\begin{array}{c}-15.358 \\
(33.35)^{* *}\end{array}$ & $\begin{array}{c}-23.678 \\
(22.57)^{* *}\end{array}$ \\
\hline Observations & 3387 & 10654 & 10654 & 10220 & 4501 \\
\hline R-squared & 0.64 & 0.60 & 0.62 & 0.62 & 0.61 \\
\hline
\end{tabular}

Absolute value of $\mathrm{t}$ statistics in parentheses

$*$ significant at $5 \%$;** significant at $1 \%$ 
Table 14. Financial Development: Recipient Country Random Effects

\begin{tabular}{|c|c|c|c|c|}
\hline & $(1)$ & $(2)$ & (3) & $(4)$ \\
\hline \multirow[t]{2}{*}{ log of GDP-source country } & 0.317 & 0.336 & 0.326 & 0.418 \\
\hline & $(28.42)^{* *}$ & $(19.75)^{* *}$ & $(28.13)^{* *}$ & $(28.51)^{* *}$ \\
\hline \multirow[t]{2}{*}{$\log$ of GDP-destination country } & 0.560 & 0.648 & 0.605 & 0.726 \\
\hline & $(20.24)^{* *}$ & $(17.96)^{* *}$ & $(21.28)^{* *}$ & $(16.13)^{* *}$ \\
\hline \multirow[t]{2}{*}{ log of Distance } & -0.673 & -0.664 & -0.664 & -0.834 \\
\hline & $(24.14)^{* *}$ & $(20.25)^{* *}$ & $(23.36)^{* *}$ & $(24.91)^{* *}$ \\
\hline \multirow[t]{2}{*}{ Land Border Dummy } & 0.175 & 0.228 & 0.178 & 0.074 \\
\hline & $(1.71)$ & $(2.04)^{*}$ & $(1.72)$ & $(0.64)$ \\
\hline \multirow[t]{2}{*}{ Common Language Dummy } & 0.271 & 0.431 & 0.288 & 0.273 \\
\hline & $(5.46)^{* *}$ & $(6.39) * *$ & $(5.62)^{* *}$ & $(4.09) * *$ \\
\hline \multirow[t]{2}{*}{ Control on bond transactions (inflow) } & -0.239 & -0.241 & -0.249 & -0.306 \\
\hline & $(2.77)^{* *}$ & $(2.28)^{*}$ & $(2.90) * *$ & $(2.67)^{* *}$ \\
\hline \multirow[t]{2}{*}{ Control on bond transactions (outflow) } & -0.683 & -0.840 & -0.724 & -0.876 \\
\hline & $(17.20)^{* *}$ & $(15.66)^{* *}$ & $(17.75)^{* *}$ & $(16.89)^{* *}$ \\
\hline \multirow[t]{2}{*}{ LIBOR - Source Country Interest Rate } & 0.012 & 0.015 & 0.008 & 0.019 \\
\hline & $(9.48)^{* *}$ & $(9.94)^{* *}$ & $(6.10) * *$ & $(7.53)^{* *}$ \\
\hline \multirow[t]{2}{*}{ Destination Country Interest Rate - LIBOR } & -0.005 & -0.004 & -0.005 & -0.003 \\
\hline & $(1.53)$ & $(0.96)$ & $(1.51)$ & $(0.43)$ \\
\hline \multirow[t]{2}{*}{ Size of Banking Sector-source country } & 0.009 & 0.012 & 0.009 & 0.010 \\
\hline & $(26.04) * *$ & $(24.73) * *$ & $(23.40)^{* *}$ & $(21.17)^{* *}$ \\
\hline \multirow[t]{2}{*}{ Size of Banking Sector-destination country } & 0.005 & 0.005 & 0.005 & 0.003 \\
\hline & $(4.78) * *$ & $(4.32)^{* *}$ & $(4.69) * *$ & $(2.07)^{*}$ \\
\hline \multirow[t]{2}{*}{ Bank Concentration Index-source country } & & -0.325 & & \\
\hline & & $(2.31)^{*}$ & & \\
\hline \multirow[t]{2}{*}{ Bank Concentration Index-destination country } & & -0.224 & & \\
\hline & & $(0.80)$ & & \\
\hline \multirow[t]{2}{*}{ Share of public bank assets-source country } & & & -0.013 & \\
\hline & & & $(9.28) * *$ & \\
\hline \multirow[t]{2}{*}{ Share of public bank assets-destination country } & & & -0.007 & \\
\hline & & & $(3.65)^{* *}$ & \\
\hline \multirow[t]{2}{*}{ Size of Stock Market-source country } & & & & 0.008 \\
\hline & & & & $(19.41)^{* *}$ \\
\hline \multirow[t]{2}{*}{ Size of Stock Market-destination country } & & & & 0.001 \\
\hline & & & & $(0.59)$ \\
\hline \multirow[t]{2}{*}{ Asia } & 0.692 & 0.539 & 0.736 & 0.121 \\
\hline & $(4.73)^{* *}$ & $(3.37)^{* *}$ & $(4.98)^{* *}$ & $(0.77)$ \\
\hline \multirow[t]{2}{*}{ EU15 } & 3.015 & 2.752 & 2.932 & 2.513 \\
\hline & $(33.99)^{* *}$ & $(28.35)^{* *}$ & $(32.70)^{* *}$ & $(26.20) * *$ \\
\hline \multirow[t]{2}{*}{ Latin America } & 0.042 & 0.275 & 0.160 & -0.201 \\
\hline & $(0.39)$ & $(2.29)^{*}$ & $(1.46)$ & $(1.25)$ \\
\hline \multirow[t]{2}{*}{ Constant } & -15.371 & -18.222 & -16.542 & -21.137 \\
\hline & $(21.24)^{* *}$ & $(17.70)^{* *}$ & $(22.11)^{* *}$ & $(18.21)^{* *}$ \\
\hline Observations & 10557 & 7553 & 10102 & 7038 \\
\hline Number of Destination Country & 132 & 89 & 124 & 85 \\
\hline R2-overall & 0.64 & 0.65 & 0.65 & 0.65 \\
\hline R2-within & 0.46 & 0.51 & 0.47 & 0.57 \\
\hline R2-between & 0.82 & 0.84 & 0.85 & 0.82 \\
\hline Breusch-Pagan LM Test for Random Effects & 16397.08 & 9351.59 & 11799.28 & 10667.40 \\
\hline Prob > Chi2 & 0.00 & 0.00 & 0.00 & 0.00 \\
\hline
\end{tabular}

Absolute value of $\mathrm{z}$ statistics in parentheses

$*$ significant at $5 \%$; ** significant at $1 \%$ 
Table 15. Investor Base Equations

\begin{tabular}{|c|c|c|c|c|c|c|c|c|c|}
\hline & \multicolumn{3}{|c|}{ Destination RE } & \multicolumn{3}{|c|}{ Destination FE } & \multicolumn{3}{|c|}{ SUR } \\
\hline & $(1)$ & $(2)$ & (3) & (4) & $(5)$ & (6) & (7) & $(8)$ & (9) \\
\hline & Banks & Insurance & $\begin{array}{l}\text { Mutual } \\
\text { Funds }\end{array}$ & Banks & Insurance & $\begin{array}{l}\text { Mutual } \\
\text { Funds }\end{array}$ & Banks & Insurance & $\begin{array}{l}\text { Mutual } \\
\text { Funds }\end{array}$ \\
\hline \multirow[t]{2}{*}{ log of GDP-source country } & 0.927 & 0.692 & 0.857 & 0.927 & 0.703 & 0.847 & 0.927 & 0.681 & 0.881 \\
\hline & $(36.38) * *$ & $(25.08)^{* *}$ & $(28.04)^{* *}$ & $(36.26)^{* *}$ & $(25.40)^{* *}$ & $(27.50)^{* *}$ & $(26.30)^{* *}$ & $(21.68)^{* *}$ & $(26.70) * *$ \\
\hline \multirow{2}{*}{$\log$ of GDP-destination country } & 0.666 & 0.648 & 0.530 & 0.077 & 0.332 & -1.825 & 0.739 & 0.734 & 0.564 \\
\hline & $(10.82)^{* *}$ & $(11.62)^{* *}$ & $(10.10)^{* *}$ & $(0.07)$ & $(0.29)$ & $(1.33)$ & $(21.80)^{* *}$ & $(24.28)^{* *}$ & $(17.79)^{* *}$ \\
\hline \multirow[t]{2}{*}{$\log$ of Distance } & -0.391 & 0.094 & -0.308 & -0.382 & 0.139 & -0.346 & -0.246 & -0.072 & -0.266 \\
\hline & $(6.35)^{* *}$ & $(1.37)$ & $(4.06) * *$ & $(5.87)^{* *}$ & $(1.91)$ & $(4.14)^{* *}$ & $(3.17)^{* *}$ & $(1.04)$ & $(3.66)^{* *}$ \\
\hline \multirow[t]{2}{*}{ Land Border Dummy } & 0.441 & 0.346 & 0.110 & 0.442 & 0.416 & 0.076 & 0.349 & 0.114 & 0.168 \\
\hline & $(2.47)^{*}$ & $(1.77)$ & $(0.47)$ & $(2.46)^{*}$ & $(2.12)^{*}$ & $(0.32)$ & $(1.28)$ & $(0.47)$ & $(0.65)$ \\
\hline \multirow[t]{2}{*}{ Common Language Dummy } & 0.644 & 0.503 & 0.061 & 0.662 & 0.502 & 0.030 & 0.538 & 0.375 & 0.075 \\
\hline & $(5.50)^{* *}$ & $(4.35)^{* *}$ & $(0.44)$ & $(5.60)^{* *}$ & $(4.29)^{* *}$ & $(0.22)$ & $(3.45)^{* *}$ & $(2.69)^{* *}$ & $(0.51)$ \\
\hline \multirow[t]{2}{*}{ Control on bond transactions (inflow) } & -0.241 & -0.403 & -0.192 & -0.182 & 0.044 & 0.152 & -0.359 & -0.570 & -0.258 \\
\hline & $(1.46)$ & $(2.60)^{* *}$ & $(1.25)$ & $(0.62)$ & $(0.14)$ & $(0.43)$ & $(3.29)^{* *}$ & $(5.86)^{* *}$ & $(2.53)^{*}$ \\
\hline \multirow[t]{2}{*}{ Control on bond transactions (outflow) } & -1.380 & -1.409 & -1.073 & -1.389 & -1.457 & -1.073 & -1.198 & -1.257 & -1.140 \\
\hline & $(16.75)^{* *}$ & $(17.32)^{* *}$ & $(10.11)^{* *}$ & $(16.72)^{* *}$ & $(17.75)^{* *}$ & $(9.90) * *$ & $(9.50)^{* *}$ & $(11.17)^{* *}$ & $(9.65)^{* *}$ \\
\hline \multirow[t]{2}{*}{ Bond Returns-source country } & 0.044 & 0.041 & 0.048 & 0.046 & 0.045 & 0.049 & 0.061 & 0.047 & 0.056 \\
\hline & $(2.03)^{*}$ & $(2.16)^{*}$ & $(2.03)^{*}$ & $(2.07)^{*}$ & $(2.33)^{*}$ & $(2.08)^{*}$ & $(2.28)^{*}$ & $(1.97)^{*}$ & $(2.24)^{*}$ \\
\hline \multirow[t]{2}{*}{ Bond Returns-destination country } & 0.043 & 0.047 & 0.054 & 0.047 & 0.034 & 0.056 & 0.075 & 0.097 & 0.055 \\
\hline & $(1.95)$ & $(2.20)^{*}$ & $(2.15)^{*}$ & $(2.01)^{*}$ & $(1.47)$ & $(1.99)^{*}$ & $(2.88)^{* *}$ & $(4.17)^{* *}$ & $(2.23)^{*}$ \\
\hline \multirow[t]{2}{*}{ Correlation of Bond Returns } & 1.067 & 2.302 & 0.659 & 1.063 & 2.410 & 0.688 & 0.323 & 1.918 & 0.562 \\
\hline & $(5.49)^{* *}$ & $(10.98)^{* *}$ & $(2.70)^{* *}$ & $(5.41)^{* *}$ & $(11.33)^{* *}$ & $(2.74)^{* *}$ & $(1.15)$ & $(7.66)^{* *}$ & $(2.14)^{*}$ \\
\hline \multirow[t]{2}{*}{ Volatility of Bilateral Exchange Rates } & -0.039 & -0.016 & -0.067 & -0.043 & -0.002 & -0.067 & -0.080 & -0.077 & -0.070 \\
\hline & $(1.99)^{*}$ & $(0.83)$ & $(2.73)^{* *}$ & $(2.08)^{*}$ & $(0.12)$ & $(2.49)^{*}$ & $(3.20)^{* *}$ & $(3.47)^{* *}$ & $(2.99)^{* *}$ \\
\hline \multirow[t]{2}{*}{ Asia } & 0.330 & 0.652 & -1.075 & 0.396 & 0.841 & -1.014 & 0.064 & 0.265 & -1.334 \\
\hline & $(1.32)$ & $(2.36)^{*}$ & $(3.24)^{* *}$ & $(1.55)$ & $(2.99)^{* *}$ & $(2.96)^{* *}$ & $(0.18)$ & $(0.84)$ & $(4.01)^{* *}$ \\
\hline \multirow[t]{2}{*}{ EU15 } & 2.244 & 2.676 & 1.739 & 2.272 & 2.578 & 1.771 & 2.802 & 2.697 & 1.705 \\
\hline & $(10.76)^{* *}$ & $(11.61)^{* *}$ & $(7.08)^{* *}$ & $(10.54)^{* *}$ & $(10.74)^{* *}$ & $(6.67)^{* *}$ & $(10.59)^{* *}$ & $(11.42)^{* *}$ & $(6.88)^{* *}$ \\
\hline \multirow{2}{*}{ Latin America } & -0.588 & 0.390 & -0.207 & -0.614 & 0.540 & -0.428 & 0.131 & 0.162 & 0.062 \\
\hline & $(2.56)^{*}$ & (1.74) & $(0.84)$ & $(2.59)^{* *}$ & $(2.30)^{*}$ & $(1.62)$ & $(0.49)$ & $(0.67)$ & $(0.24)$ \\
\hline \multirow[t]{2}{*}{ Constant } & -35.908 & -33.980 & -31.487 & -20.726 & -26.616 & 29.997 & -39.148 & -34.300 & -33.245 \\
\hline & $(19.81)^{* *}$ & $(19.26)^{* *}$ & $(18.12)^{* *}$ & $(0.74)$ & $(0.91)$ & $(0.84)$ & $(26.21)^{* *}$ & $(25.74)^{* *}$ & $(23.78)^{* *}$ \\
\hline Observations & 2,517 & 1,749 & 1,509 & 2,517 & 1,749 & 1,509 & 1,351 & 1,351 & 1,351 \\
\hline Number of Destination Country & 52 & 52 & 52 & 52 & 52 & 52 & & & \\
\hline R-squared & 0.81 & 0.83 & 0.73 & 0.62 & 0.65 & 0.58 & 0.68 & 0.72 & 0.63 \\
\hline
\end{tabular}

Absolute value of $t$ statistics in parentheses

$*$ significant at $5 \%$;* significant at $1 \%$ 


\section{Appendix I: List of Participants in CPIS}

\begin{tabular}{|l|c|c|c|}
\hline & 2001 & 2002 & 2003 \\
\hline Argentina & 1 & 1 & 1 \\
\hline Aruba & 1 & 1 & 1 \\
\hline Australia & 1 & 1 & 1 \\
\hline Austria & 1 & 1 & 1 \\
\hline Bahamas, The & 1 & 1 & 1 \\
\hline Bahrain & 1 & 0 & 0 \\
\hline Barbados & 0 & 0 & 1 \\
\hline Belgium & 1 & 1 & 1 \\
\hline Bermuda & 1 & 1 & 1 \\
\hline Brazil & 1 & 1 & 1 \\
\hline Bulgaria & 1 & 1 & 1 \\
\hline Canada & 1 & 1 & 1 \\
\hline Cayman Islands & 1 & 1 & 1 \\
\hline Chile & 1 & 1 & 1 \\
\hline Colombia & 1 & 1 & 1 \\
\hline Costa Rica & 1 & 1 & 1 \\
\hline Cyprus & 1 & 1 & 1 \\
\hline Czech Republic & 1 & 1 & 1 \\
\hline Denmark & 1 & 1 & 1 \\
\hline Egypt & 1 & 1 & 1 \\
\hline Estonia & 1 & 1 & 1 \\
\hline Finland & 1 & 1 & 1 \\
\hline France & 1 & 1 & 1 \\
\hline Germany & 1 & 1 & 1 \\
\hline Greece & 1 & 1 & 1 \\
\hline Guernsey & 1 & 1 & 1 \\
\hline Hong Kong SAR of China & 1 & 1 & 1 \\
\hline Hungary & 1 & 1 & 1 \\
\hline Iceland & 1 & 1 & 1 \\
\hline Indonesia & 1 & 1 & 1 \\
\hline Ireland & 1 & 1 & 1 \\
\hline Isle of Man & 1 & 1 & 1 \\
\hline Israel & 1 & 1 & 1 \\
\hline Italy & 1 & 1 & 1 \\
\hline Japan & 1 & 1 & 1 \\
\hline Jersey & 1 & 1 & 1 \\
\hline Kazakhstan & 1 & 1 \\
\hline Korea, Republic of & 1 & 1 \\
\hline Lebanon & 1 & 1 \\
\hline Luxembourg & 1 & 1 \\
\hline Macao SAR of China & 1 \\
\hline Malaysia & 1 & \\
\hline
\end{tabular}

\begin{tabular}{|l|c|c|c|}
\hline & 2001 & 2002 & 2003 \\
\hline Malta & 1 & 1 & 1 \\
\hline Mauritius & 1 & 1 & 1 \\
\hline Mexico & 0 & 0 & 1 \\
\hline Netherlands & 1 & 1 & 1 \\
\hline Netherlands Antilles & 1 & 1 & 1 \\
\hline New Zealand & 1 & 1 & 1 \\
\hline Norway & 1 & 1 & 1 \\
\hline Pakistan & 0 & 1 & 1 \\
\hline Panama & 1 & 1 & 1 \\
\hline Philippines & 1 & 1 & 1 \\
\hline Poland & 1 & 1 & 1 \\
\hline Portugal & 1 & 1 & 1 \\
\hline Romania & 1 & 1 & 1 \\
\hline Russian Federation & 1 & 1 & 1 \\
\hline Singapore & 1 & 1 & 1 \\
\hline Slovak Republic & 1 & 1 & 1 \\
\hline South Africa & 1 & 1 & 1 \\
\hline Spain & 1 & 1 & 1 \\
\hline Sweden & 1 & 1 & 1 \\
\hline Switzerland & 1 & 1 & 1 \\
\hline Thailand & 1 & 1 & 1 \\
\hline Turkey & 1 & 1 & 1 \\
\hline Ukraine & 1 & 1 & 1 \\
\hline United Kingdom & 1 & 1 & 1 \\
\hline United States & 1 & 1 & 1 \\
\hline Uruguay & 1 & 1 & 1 \\
\hline Vanuatu & 1 & 1 & 1 \\
\hline Venezuela & 1 & 1 & 1 \\
\hline & & & \\
\hline Total & 67 & 67 & 69 \\
\hline
\end{tabular}


Appendix II. Data Description

\begin{tabular}{|c|c|c|}
\hline Variable & Description & Source \\
\hline GDP & GDP at current US\$ & World Bank's WDI \\
\hline GDP per capita & GDP per capita at current US\$ & World Bank's WDI \\
\hline GDP, PPP & GDP adjusted for purchasing power parity & World Bank's WDI \\
\hline Distance & Distance between countries (in logs) & Andrew Rose's website \\
\hline Land border dummy & $\begin{array}{l}\text { Dummy variable }=1 \text { if the two countries share a land } \\
\text { border }\end{array}$ & Andrew Rose's website \\
\hline $\begin{array}{l}\text { Common language } \\
\text { dummy }\end{array}$ & $\begin{array}{l}\text { Dummy variable }=1 \text { if the two countries have a } \\
\text { common language }\end{array}$ & Andrew Rose's website \\
\hline Time zone difference & $\begin{array}{l}\text { Time difference between financial centers of the } \\
\text { countries in hours (in June). The variable ranges } \\
\text { from } 0 \text { to } 12 .\end{array}$ & www.worldtimezone.com \\
\hline $\begin{array}{l}\text { Control on bond } \\
\text { transactions (inflow) }\end{array}$ & $\begin{array}{l}\text { Dummy variable }=1 \text { if there is a restriction on inflow } \\
\text { transaction of bonds or other debt securities }\end{array}$ & $\begin{array}{l}\text { IMF's Annual Report on Exchange } \\
\text { Arrangements and Exchange } \\
\text { Restrictions }\end{array}$ \\
\hline $\begin{array}{l}\text { Control on bond } \\
\text { transactions } \\
\text { (outflow) }\end{array}$ & $\begin{array}{l}\text { Dummy variable }=1 \text { if there is a restriction on outflow } \\
\text { transaction of bonds or other debt securities }\end{array}$ & $\begin{array}{l}\text { IMF's Annual Report on Exchange } \\
\text { Arrangements and Exchange } \\
\text { Restrictions }\end{array}$ \\
\hline LIBOR & London Interbank Offer Rate & IMF's International Financial Statistics \\
\hline Interest rate & Treasury bill rate & IMF's International Financial Statistics \\
\hline Exchange Rate & Bilateral (crossed) exchange rate & IMF's International Financial Statistics \\
\hline Historical Bond Returns & Total bond return index--see text & Bloomberg \\
\hline Size of Banking Sector & Bank credit to private sector & IMF's International Financial Statistics \\
\hline Size of Stock Market & Stock market capitalization & IMF's International Financial Statistics \\
\hline Law and Order Risk & $\begin{array}{l}\text { Political risk rating component on law and order } \\
\text { (higher values means lower risks) }\end{array}$ & International Country Risk Guide \\
\hline Corruption Risk & $\begin{array}{l}\text { Political risk rating component on corruption (higher } \\
\text { values means lower risks) }\end{array}$ & International Country Risk Guide \\
\hline Bureaucratic Quality & $\begin{array}{l}\text { Political risk rating component on quality of } \\
\text { bureaucracy (higher values means lower risks) }\end{array}$ & International Country Risk Guide \\
\hline Investment Profile & $\begin{array}{l}\text { Political risk rating component on assessment of } \\
\text { investment risks (higher values means lower } \\
\text { risks) }\end{array}$ & International Country Risk Guide \\
\hline $\begin{array}{l}\text { Sovereign Credit } \\
\text { Ratings }\end{array}$ & $\begin{array}{l}\text { Numerical variable ranging from } 0-20 ; 0 \text { is equivalent } \\
\text { to the rating "default" and } 20 \text { is AAA }\end{array}$ & Standard \& Poor's \\
\hline Legal origin & $\begin{array}{l}\text { dummy variables identifying the legal origin of the } \\
\text { company law or commercial code of each country. } \\
\text { The five origins are English, French, German, } \\
\text { Nordic and Socialist. }\end{array}$ & Djankov et. al. (2005) \\
\hline Creditor's rights & $\begin{array}{l}\text { Index of creditor rights, ranging from } 0 \text { (weak) to } 4 \\
\text { (strong creditor rights) }\end{array}$ & Djankov et. al. (2005) \\
\hline Contract enforcement & $\begin{array}{l}\text { The number of days to resolve a payment dispute } \\
\text { through courts }\end{array}$ & Djankov et. al. (2005) \\
\hline $\begin{array}{l}\text { Share of public bank } \\
\text { assets }\end{array}$ & $\begin{array}{l}\text { Ratio of public commercial banks' assets to total } \\
\text { banking assets }\end{array}$ & $\begin{array}{l}\text { Micco, Panizza and Yañez (2004) and } \\
\text { Bankscope }\end{array}$ \\
\hline Bank concentration & HHI index of commercial bank assets & Bankscope \\
\hline $\begin{array}{l}\text { de facto exchange } \\
\text { rate regime }\end{array}$ & $\begin{array}{l}\text { Reinhart-Rogoff de facto exchange rate regime } \\
\text { classification }\end{array}$ & $\begin{array}{l}\text { Eichengreen and Razo-Garcia } \\
(2005)\end{array}$ \\
\hline Phone traffics & Minutes of incoming and outgoing telephone traffics & International Telecommunication Union \\
\hline Phone costs & $\begin{array}{l}\text { Costs of international call (US\$ per } 3 \text { minutes in peak } \\
\text { hours to USA; for USA to Europe) }\end{array}$ & World Competitiveness Yearbook \\
\hline
\end{tabular}

